\title{
Does the Phytochemical Diversity of Wild Plants Like the Erythrophleum genus Correlate with Geographical Origin?
}

\author{
Cédric Delporte ${ }^{1,2, *,+}{ }^{\circ}$, Nausicaa Noret ${ }^{3,+}$, Cécile Vanhaverbeke ${ }^{4}\left(\mathbb{D}\right.$, Olivier J. Hardy ${ }^{5}$, Jean-François Martin ${ }^{6}$, \\ Marie Tremblay-Franco ${ }^{6}$, David Touboul ${ }^{7}$ (D), Anais Gorel ${ }^{8}$, Marie Faes ${ }^{1}$, Caroline Stévigny ${ }^{1}$, \\ Pierre Van Antwerpen ${ }^{1,2}$ and Florence Souard $4,9, *$
}

Citation: Delporte, C.; Noret, N.; Vanhaverbeke, C.; Hardy, O.J.; Martin, J.-F.; Tremblay-Franco, M.; Touboul, D.; Gorel, A.; Faes, M.; Stévigny, C.; et al. Does the Phytochemical Diversity of Wild Plants Like the Erythrophleum genus Correlate with Geographical Origin?. Molecules 2021, 26, 1668. https://doi.org/10.3390/ molecules26061668

Academic Editor: Lars Porskjær Christensen

Received: 23 February 2021

Accepted: 15 March 2021

Published: 17 March 2021

Publisher's Note: MDPI stays neutral with regard to jurisdictional claims in published maps and institutional affiliations.

Copyright: (c) 2021 by the authors. Licensee MDPI, Basel, Switzerland. This article is an open access article distributed under the terms and conditions of the Creative Commons Attribution (CC BY) license (https:/ / creativecommons.org/licenses/by/ $4.0 /)$.
1 RD3-Pharmacognosy, Bioanalysis and Drug Discovery, Faculté de Pharmacie, Université libre de Bruxelles, Campus Plaine, CP 205/05, 1050 Brussels, Belgium; marie.faes@ulb.be (M.F.); caroline.stevigny@ulb.be (C.S.); pierre.van.antwerpen@ulb.be (P.V.A.)

2 Analytical Platform of the Faculty of Pharmacy, Faculté de Pharmacie, Université libre de Bruxelles, Campus Plaine, CP 205/05, 1050 Brussels, Belgium

3 Laboratoire d'Écologie végétale et Biogéochimie, Faculté des Sciences, Université libre de Bruxelles, Campus Plaine, CP 244, 1050 Brussels, Belgium; Nausicaa.Noret@ulb.ac.be

4 Département de Pharmacochimie Moléculaire (DPM), Univiversité Grenoble Alpes, CNRS, 38000 Grenoble, France; cecile.vanhaverbeke@univ-grenoble-alpes.fr

5 Evolutionary Biology and Ecology, Faculté des Sciences, Université libre de Bruxelles, Campus du Solbosch, CP 160/12, 1050 Brussels, Belgium; olivier.hardy@ulb.ac.be

6 Toxalim, Research Centre in Food Toxicology, Toulouse University, INRAE, UMR 1331, PF MetaToul-AXIOM, 31027 Toulouse, France; jean-francois.martin@inrae.fr (J.-F.M.); marie.tremblay-franco@inrae.fr (M.T.-F.)

7 CNRS, Institut de Chimie des Substances Naturelles, Université Paris-Saclay, UPR 2301, 91198 Gif-sur-Yvette, France; david.touboul@cnrs.fr

8 Laboratory of Plant Ecology, Department of Plants and Crops, Faculty of Bioscience Engineering, Ghent University, 9052 Ghent, Belgium; AnaisPasiphae.Gorel@UGent.be

9 Department of Pharmacotherapy and Pharmaceutics, Faculté of Pharmacie, Université libre de Bruxelles, 1050 Brussels, Belgium

* Correspondence: cedric.delporte@ulb.be (C.D.); florence.souard@ulb.be (F.S.)

+ These authors contributed equally to the work.

Abstract: Secondary metabolites are essential for plant survival and reproduction. Wild undomesticated and tropical plants are expected to harbor highly diverse metabolomes. We investigated the metabolomic diversity of two morphologically similar trees of tropical Africa, Erythrophleum suaveolens and E. ivorense, known for particular secondary metabolites named the cassaine-type diterpenoids. To assess how the metabolome varies between and within species, we sampled leaves from individuals of different geographic origins but grown from seeds in a common garden in Cameroon. Metabolites were analyzed using reversed phase LC-HRMS(/MS). Data were interpreted by untargeted metabolomics and molecular networks based on MS/MS data. Multivariate analyses enabled us to cluster samples based on species but also on geographic origins. We identified the structures of 28 cassaine-type diterpenoids among which 19 were new, 10 were largely specific to $E$. ivorense and five to E. suaveolens. Our results showed that the metabolome allows an unequivocal distinction of morphologically-close species, suggesting the potential of metabolite fingerprinting for these species. Plant geographic origin had a significant influence on relative concentrations of metabolites with variations up to eight (suaveolens) and 30 times (ivorense) between origins of the same species. This shows that the metabolome is strongly influenced by the geographical origin of plants (i.e., genetic factors).

Keywords: eco-metabolomics; plant-omics; plant fingerprint; metabolomics; natural variation; molecular networks; cassane-type diterpenes; specialized metabolites; geographic variation; phytochemical 


\section{Introduction}

As sessile organisms, plants produce thousands of secondary metabolites [1-4] to cope with various environmental constraints [5]. Plant natural products are produced via numerous specialized enzymes that transform central/primary metabolites into secondary metabolites. The latter provide tremendous resources for human therapies [6]. The metabolome is often observed as the "readout" of the physiological status and the bridge between genotype and phenotype [7]. Given the importance of plant secondary metabolism for plant survival and reproduction, and for human health, various studies have been performed to understand the genetic regulation of plant metabolism [8,9]. As metabolites are end products of complex cellular networks of gene expression, protein synthesis and interactions, and are likely under natural selection, they are more accurate measures of the phenotype than transcriptomic or proteomic data alone [10-12].

The literature mostly focuses on the description of the metabolome of different species [13-15], often crops or model plants, and little is known about variation within wild species. Here, we investigate the variation of genetic basis within two closely-related species, and we compare the levels of intra- and inter-species variation. As our aim is to study natural variation, we focused on wild plants that have not been modified by humans. In this context, Erythrophleum genus is an ideal study case of wild undomesticated plants containing original human-bioactive metabolites. Erythrophleum (FabaceaeCaesalpinioideae) is a pantropical woody genus that includes around 15 species with representatives found in North-East Asia, Australia, and Africa [16].

In Africa, E. suaveolens (sua) and E. ivorense (ivo) are two species found in wild tropical forests. Morphologically they are very similar and both species are often confused, particularly in the absence of reproductive organs, and both are called "tali" by local people [16]. E. ivorense is present in high rainfall evergreen and semi-evergreen tropical forests from West Africa to western Central Africa, from Gambia to Gabon. E. suaveolens is more widespread, occurring in West, Central and Austral Africa, and tolerates a wider range of climatic conditions. This species is thus found in drier, semi-evergreen forests, in savannahs, and in gallery forests, from Senegal to Sudan and Kenya, as well as south to Mozambique and Zimbabwe [16]. Population genetics research conducted in West and Central Africa showed that each species can be subdivided in three genetic groups occurring in parapatry or allopatry, presumably as a legacy of ancient population fragmentations when the forest cover had contracted due to Quaternary climate changes (glacial episodes) [14].

Erythrophleum species have a particular metabolome composed a priori of large amounts of molecules with the specific cassane-type diterpene scaffold [17-19]. These are specific scaffolds long recognized for cardiac effects in humans [20]. Cassane-type diterpenes usually named as "cassaine alkaloids" or "Erythrophleum alkaloids" were long known as the main specialized metabolites found in the Erythrophleum genus [21] whereas the distribution of nor-cassane diterpenes is restricted to Caesalpinia [22]. Cassaine diterpene has a basic skeleton of the cassane-type (Figure 1). Cassane diterpenoids have been widely studied and their structural diversity is impressive (a SciFinder ${ }^{\mathrm{n}}$ search reveals 408 cassane type structures published in 334 references until January 2021 in Chemical Abstracts). The basic cassane type skeleton consists of a tricyclic diterpene with 20 carbon atoms, where the carbon in position C-13 is substituted by an ethyl group and the carbon in C-14 is substituted by a methyl group (Figure 1A). Various biosynthetic pathways have been proposed [23-25], in which cassane-type diterpenes are thought to be derived from biosynthetic rearrangements of the pimarane precursor $\Delta^{8}, 15$,-pimaradiene, itself originating from the cyclization of $\Delta^{8}, 15$,-labdadienyl pyrophosphate (LDPP) obtained from geranylgeranyl pyrophosphate (GGPP) in the terpenoid biosynthetic pathway (mevalonate pathway) (Figure 1A). The cassane-type backbone would derive from pimarane following migration of the methyl group carried by the carbon in position C-13 to the carbon in position C-14. 
A

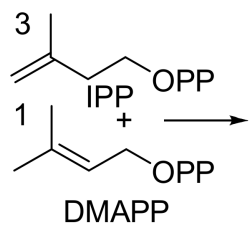

DMAPP

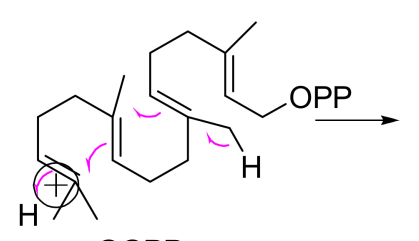

GGPP

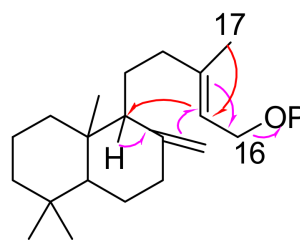

LDPP

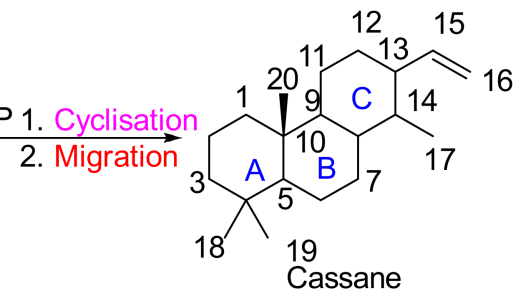

Cassane
B

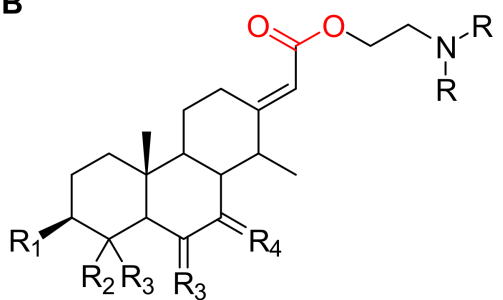

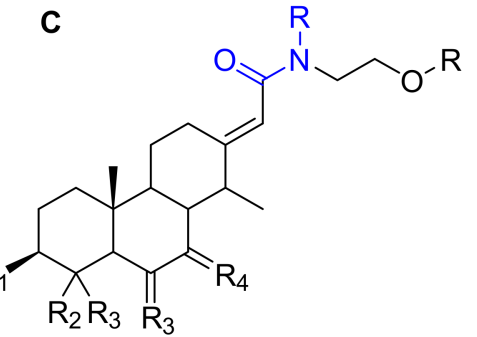

Figure 1. (A) Possible biosynthesis pathways for basic skeletons of cassane-types diterpenoids. Three molecules of isopentenyl pyrophosphate (IPP) react with a dimethylallyl pyrophosphate (DMAPP) which form geranylgeranyl pyrophosphate (GGPP) in the mevalonate pathway. The latter rearrange into $\Delta^{8}, 15$-labdadienyl pyrophosphate (LDPP) which itself rearranges into cassane-type diterpene via cyclisation and migration. (B,C) Basic skeletons of cassane-type diterpenes with (B) an ester or (C) amide arm where R substituents are H, Me or any chain and RX.

In the largest family of cassane-type diterpenes, the cassaine-type ones are a subfamily of molecules which have at the C-13 position a side chain containing a nitrogen atom in various positions. Cassaine was initially isolated from E. suaveolens in 1935 [21]. Since then, a large number of different molecules have been described, differing in their substitution patterns at the level of the tricyclic skeleton and of the chain at the $\mathrm{C}-13$ position. Cassainetype diterpenoids fall into two groups: cassaine-type ester amine diterpenoids (Figure 1B) and cassaine-type amide diterpenoids (Figure 1C) $[25,26]$ with the following particularities:

- Cassaine-type diterpenoids with an ester amine arm (Figure 1B) result from esterification between the carboxylic group of a cassane-type tricyclic diterpene acid and the alcohol group of an aminoethanol (often $\mathrm{N}$-methylethanolamine $\left(\mathrm{CH}_{3}-\mathrm{NH}-\mathrm{CH}_{2}-\mathrm{CH}_{2}-\right.$ $\mathrm{OH})$ or $\mathrm{N}, \mathrm{N}$-dimethylethanolamine $\left.\left(\left(\mathrm{CH}_{3}\right)_{2} \mathrm{~N}-\mathrm{CH}_{2}-\mathrm{CH}_{2}-\mathrm{OH}\right)\right)$ [26]. Ethanolamine can be formed by decarboxylation of a serine or by a transamination reaction (exchange of an amine group) between a glycoaldehyde and a glutamic acid [24,25].

- Cassaine-type diterpenoids with an amide alcohol arm (Figure 1C) follow the same biosynthetic pathway but the last step is likely the binding of a diterpenic acid to $\mathrm{N}$-methylethanolamine leading to an alcohol function at the end of the arm $[24,25]$.

In this work, we investigated the molecular diversity of plant metabolism in vivo using leaves from young trees of E. suaveolens and E. ivorense from different geographic origins but grown in a common garden experiment in Cameroon. Knowing the remarkable secondary metabolites composition of Erythrophleum, we investigated whether metabolomics would enable us to discriminate the two Erythrophleum species, the intraspecific genetic groups and/or the geographical origins of trees, using liquid chromatography coupled to a high-resolution tandem mass spectrometer (LC-HRMS(/MS)). Moreover, we investigated if particular cassaine-type diterpenoids can be identified as biomarkers of either species and/or origins. For this purpose, LC-HRMS(/MS) data were interpreted by both untargeted metabolomics using the Workflow4metabolomics platform (W4M) [27] and molecular networks using the MZ-Mine and MetGem softwares [28,29]. In fact, Ernst et al. have demonstrated [30] that molecular networks coupled with relevant ecological data provide a robust workflow for investigating plant specialized metabolites in a chemo-evolutionary 
context. Therefore, we aimed to answer the following questions: (1) do the metabolomes of both Erythrophleum species differ in metabolites and/or their relative abundances? (2) do the metabolomes of conspecific trees from different geographic origins differ?

\section{Results}

\subsection{Metabolomics Analysis}

Data analysis using the W4M platform enabled us to detect 1186 features (i.e., one $m / z$ [mass/charge] value at one retention time) among the 127 samples (composed of three replicates per plant sample). Principal component analysis (PCA) clearly distinguished the two species, E. ivorense and E. suaveolens, along the first axis (PC1) accounting for $49 \%$ of the variance (Figure 2A). This means that despite the morphological similarity of these two species, their phytochemical profiles are clearly distinct. The second axis explained $8 \%$ of the variance and was obviously related to intraspecific variation (data not shown), especially in E. ivorense. Figure 2A shows that features distributed on the negative values of axis 1 ( $\mathrm{PC} 1$ ) are distinctive of $E$. ivorense whereas those on the positive values are specific or more abundant in E. suaveolens. Focusing on E. suaveolens, PCA plots also show intraspecific variation (axis 2, PC2), especially between northern (CONG, UFA identified by suaN in blue) and southern (LAST, MEK identified by SuaS in green) populations. The high percentage of variance (57\%) explained by the first two axes (PC1 + PC2) suggests that hereditary genetic factors predominantly influence the metabolome compared to environmental growth factors as they were cultivated in the same forest concession (common garden). They were wild plants that were not selected, domesticated and crossed [16], so there is a high possibility that the genetics of these species should be very diverse from the adaptation of the wild plant to their geographical origins.

Table 1. Geographic origins and genetic groups of the Erythrophleum plant material analyzed for metabolomics diversity in the present study. Location of plants in the four experimental blocks and the number of individuals per origin $(n)$ are detailed in the last two columns.

\begin{tabular}{cccccc}
\hline \multirow{2}{*}{ Species } & $\begin{array}{c}\text { Population/ } \\
\text { Country }\left(^{*}\right.\end{array}$ & $\begin{array}{c}\text { GPS Coordinates } \\
\text { (Long/Lat) }\end{array}$ & Genetic Groups (**) & $\begin{array}{c}\text { Block Abbreviation } \\
\text { (Number of Individuals) }\end{array}$ & $\boldsymbol{n}$ \\
\hline \multirow{2}{*}{$\begin{array}{c}\text { E. ivorense } \\
\text { E. suaveolens }\end{array}$} & Libreville/C & $9.3727 / 0.6187$ & Ivo & $\mathrm{A}(5), \mathrm{B}(6), \mathrm{C}(7), \mathrm{D}(5)$ & 23 \\
& Ouesso/RC & $16.4892 / 1.2926$ & Ouesso-Sua (N) & $\mathrm{A}(4), 2 \mathrm{~B}(1), \mathrm{C}(2), \mathrm{D}(3)$ & 10 \\
\cline { 2 - 6 } & UFA30/C & $13.9128 / 3.4287$ & Sua (N) & $\mathrm{A}(1), \mathrm{B}(2), \mathrm{C}(1), \mathrm{D}(4)$ & 8 \\
\cline { 2 - 6 } & Lastourville \& & $12.952 /-0.5345 \&$ & Sua (S) & $\mathrm{C}(1), \mathrm{D}(2)$ & 3 \\
\hline
\end{tabular}

$\left({ }^{*}\right) \mathrm{C}=$ Cameroon, RC $=$ Republic of the Congo, G = Gabon; GPS coordinates correspond to locations of original populations. $\left({ }^{* *}\right)$ Genetic groups based on microsatellite markers refer to the assignment of the different populations inside a larger genetic groups [10]. Ivo = ivorense; SuaN = suaveolens central North, SuaS = suaveolens central South based on reference [16]. 
A

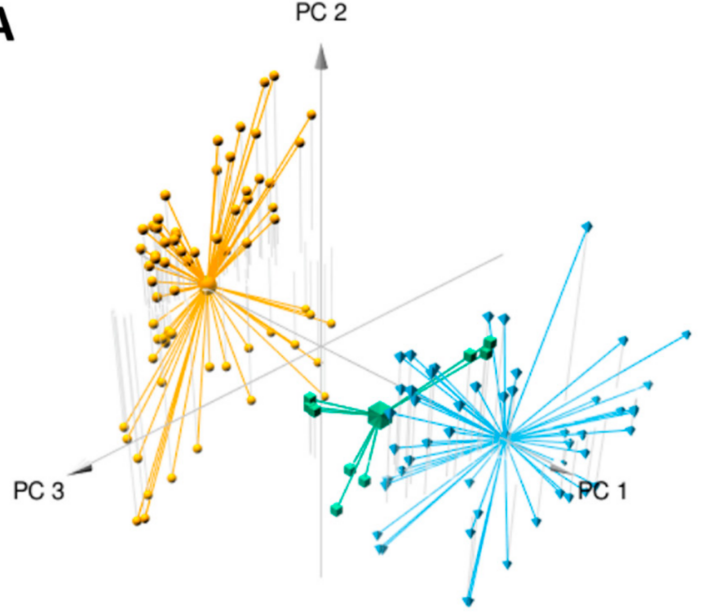

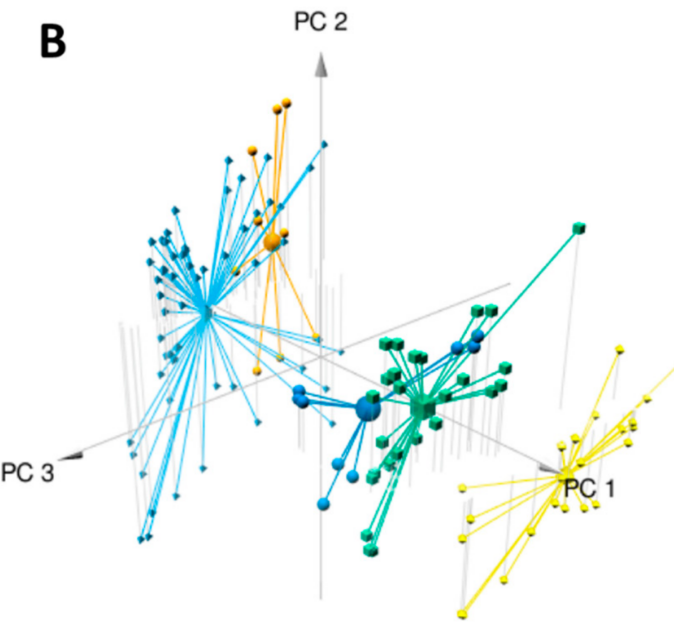

Figure 2. Multivariate modeling using PCA of metabolomics variation in samples from Erythrophleum species (E. ivorense and E. suaveolens). The three first components are plotted and percentages of variance explained by PC1, PC2 and PC3 are respectively $49 \%, 8 \%$ and $7 \%$. $\mathrm{R}^{2} \mathrm{X}$ of the PCA model is 0.648 . (A) Samples are colored corresponding to the three groups based on species E. ivorense (ivo) in orange, E. suaveolens North (sua(N)) in blue and E. suaveolens South (sua(S)) in green (see Table 1 for details). (B) The PCA was drawn with groups identified in the heatmap as a grouping factor (see Figure 3). In light blue ivo-Libr 2, in orange ivo-Libr 1, in green + dark blue Sua * (sua(N) + sua(S) see Table 1) and in yellow Ouesso-Sua.

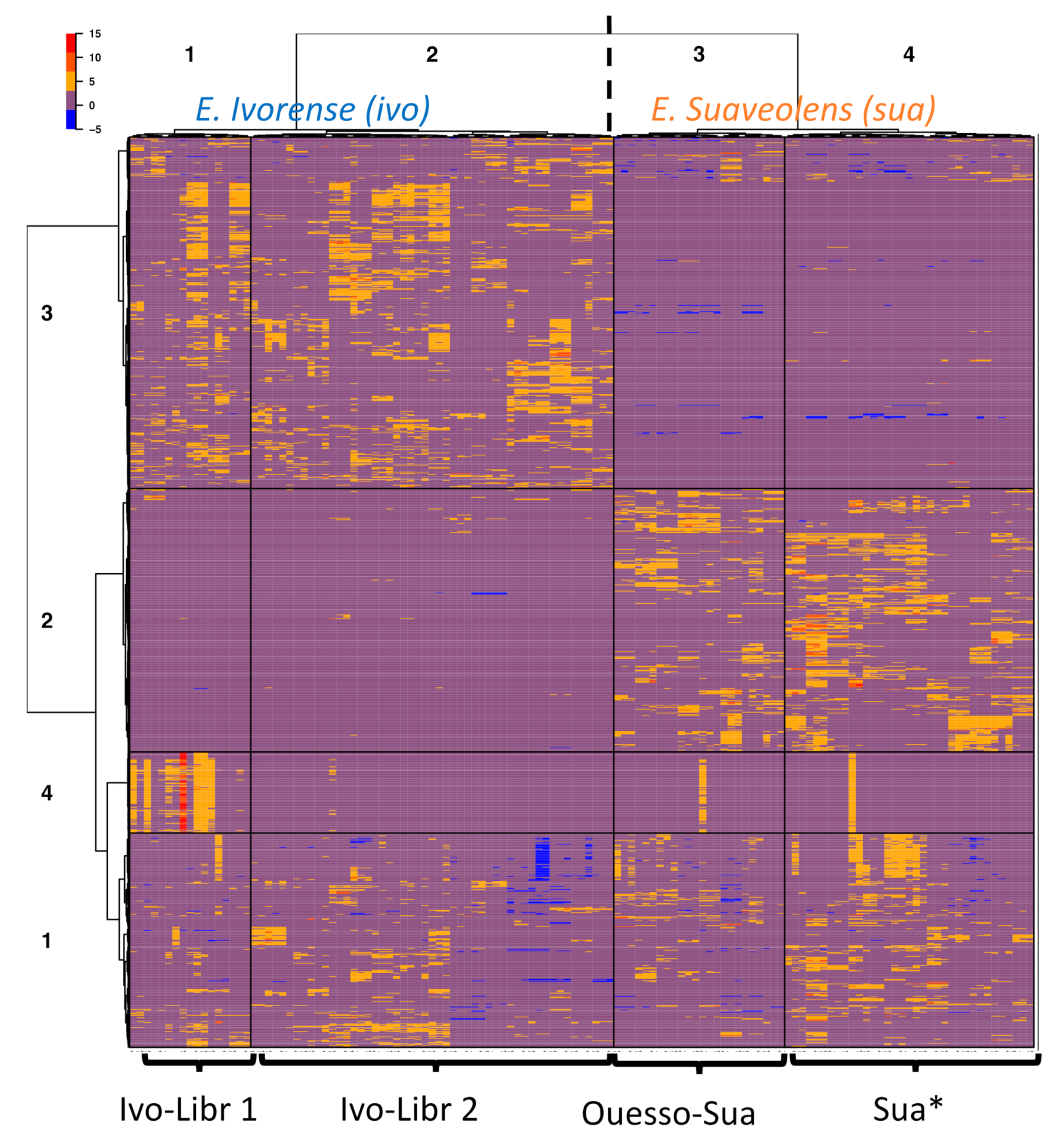

Figure 3. Heatmap clustering representation of metabolic diversity in two Erythrophleum species. Samples are in columns and features in rows. Hierarchical clustering splits E. ivorense (ivo) into 2 clusters named ivo-Libr 1 (=cluster 1) \& ivo-Libr 2 (=cluster 2), and E. suaveolens (sua) is splitted into 2 clusters named Ouesso-Sua (=cluster 3 ) and Sua * (=cluster 4$)$. 
To further study the grouping of samples based on feature similarity, hierarchical clustering was performed without a priori grouping information (Figure 3). A heatmap is a graphical representation of a data matrix where each column represents a sample and each row corresponds to a feature (i.e., one $m / z$ [mass/charge] value at one retention time) with the ion relative abundance detected in each sample represented by color intensity. In most cases, extraction replicates of a same plant sample were grouped together in the hierarchical clustering dendrogram, and they always belonged to the same sample cluster, which validates our extraction protocol. Rows (features) and columns (samples) of the matrix clustered each in four main groups. Approximately 270 features from the sample cluster 1 are common to all samples. As expected, the two species appeared as two main clusters (sample clusters 1 and 2: E. ivorense; and sample clusters 3 and 4: E. suaveolens). The two species are distinguished by higher and lower abundances of ions of the feature cluster 2 and 3, respectively, in E. suaveolens compared to E. ivorense. Unexpectedly, E. ivorense samples were split into two subgroups (clusters 1 and 2: E. ivorense, named "ivo-Libr 1" and "ivo-Libr 2") even though they all come from one population. Regarding E. suaveolens, the two sample clusters 3 and 4 were not divided according to genetic groups $($ sua $(\mathrm{N})$ and sua(S)) as would be expected. In contrast, cluster 3 includes the eastern most population named "Ouesso-Sua", whereas cluster 4 (named "Sua *") includes all other suaN and suaS samples. These results are coherent with PCA score plot showing the stretching on PC2 axis of PCA of ivorense data (Figure 2A) accounted for a group of features located on the negative values of PC2 axis. Obviously, a large set ( 18\%) of metabolic features are clearly more abundant in the ivo-Libr 1 subgroup corresponding to sample cluster 1 (red color on the heatmap, feature cluster 4 in sample cluster 1, Figure 3) whereas their concentrations are not variable in the other samples (except one replicate of two samples in E. suaveolens).

Considering the clustering organization shown in the heatmap, a PCA analysis including the five populations (Table 1) was performed and plotted (Figure 2B). The 3D-view shows that the four groups (one group cluster two populations) are distributed along the PC1 axis from lower to higher values: light blue for ivo-Libr 2, orange for ivo-Libr 1 , Sua * divided in dark blue (=sua (S)) and in green (=sua (N) from Table 1) and finally yellow for Ouesso-Sua. This stretching of populations along PC1 shows that this axis (PC1) includes both inter- and intraspecific variability. The PCA confirms that the sua(N) and sua(S) genetic groups within the Sua * cluster do not differ at the metabolome level.

\subsection{Molecular Networks}

Molecular networks aim to represent the relationships between features based on their structural similarity, which is assessed by similar MS/MS spectra. MS/MS spectra having a strong spectral similarity (cosine score (CS) $>0.55$ in our case) are represented as connected nodes. Thus, bonds between nodes appear on molecular networks as soon as the CS is higher than 0.55 and at least ten common fragment ions are detected.

Based on the cassane-type diterpenoid scaffold, there are two possibilities for the biosynthetic linkage of the arm on C-13 $\left(\mathrm{HO}-\mathrm{CH}_{2}-\mathrm{CH}_{2}-\mathrm{NH}_{2}\right.$, Figure 1$)$ to form either an amide or an ester (cassane-amide/ester analogs). Either the arm is connected by the alcohol and forms an ester arm (Figure 1B), or the link is made by the amine and in this case an amide is formed (Figure 1C). As a matter of fact, little is known about the cassane diterpenoid MS/MS fragmentation [17,19,24,26,31]. We obtained from the Champy team [18] purified fractions of cassane-type diterpenes from the ester and the amide families. LC-MS/MS analyses were carried out at different collision energies and corresponding MS/MS data were analyzed (see Supplementary Figure S1 for fragmentation description and Figure 4). The main difference between the amide and ester families is the fragmentation of the arm on $\mathrm{C}-13$ of the cassane diterpene cycle. Amide compounds with a terminal alcohol were characterized by a neutral loss of water $(-18.0109, \delta=1.15 \mathrm{ppm})$ and $\mathrm{CH}_{3} \mathrm{OH}(-32.0262$, $\delta=0.93 \mathrm{ppm})$. Concerning the ester compounds with a terminal methylamine on the arm, a neutral loss of $\mathrm{CH}_{3} \mathrm{NH}_{2}(-31.0422, \delta=12.64 \mathrm{ppm})$ was observed. It is noteworthy that a common loss of $\mathrm{C}_{3} \mathrm{H}_{9} \mathrm{NO}$ was also observed for both ester and amide compounds 
which corresponded to respective ester or amide cut of the arm $(-75.068, \delta=5.51 \mathrm{ppm})$ (Supplementary Figure S1).

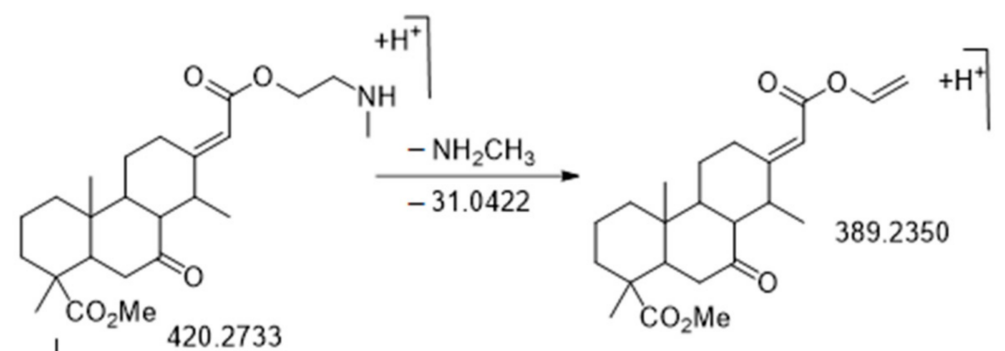

[1]

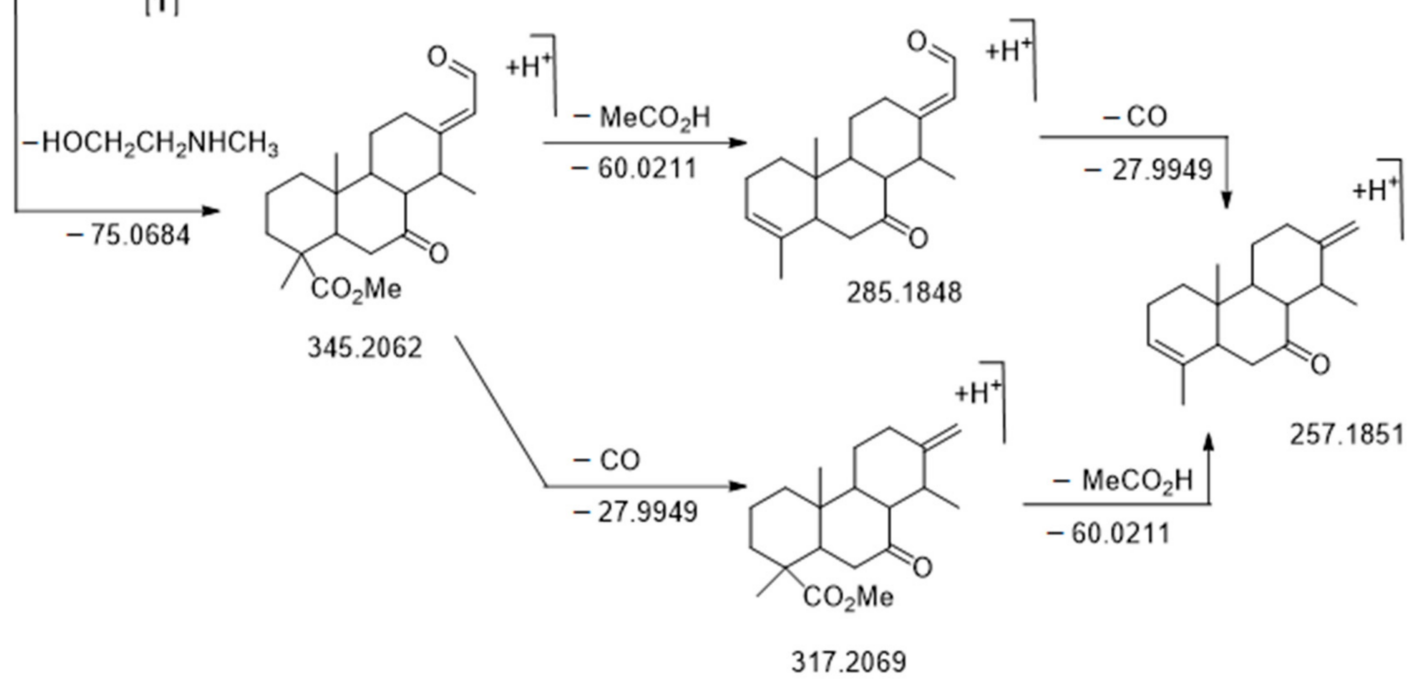

Figure 4. Fragmentation pattern of $\mathrm{C}_{24} \mathrm{H}_{37} \mathrm{NO}_{5} \mathrm{~m} / z 420.2733 \mathrm{RT}=16.97 \mathrm{~min}$, nor-cassamine [A1]. The $m / z$ values of neutral loss are calculated while the $m / z$ values of fragments are observed. All $\delta$ ppm are under $20 \mathrm{ppm}$.

Given the lack of data in MS/MS databases concerning the other cassane-type diterpenes, we have chosen to explore our dataset by using molecular networks. MetGem software [28] was used to visualize networks after a MZmine 2 preprocessing [29]. This work aims at having molecular information on the different clusters, by observing the four subgroups ivo-Libr 1, ivo-Libr 2, Ouesso-Sua and Sua * (Figures 5 and 6 and Table 2). The molecular network was built by analyzing all the MS/MS data and grouping intensities for each feature of each group. The means have been calculated of all the samples within the four subgroups (ivo-Libr1, ivo-Libr2, Ouesso-sua and Sua *). Data analysis revealed different MS/MS sub-clusters and the first and biggest one has been attributed to cassane-type diterpenes (Figures 5 and 6 and Table 2) thanks to Champy's sample analysis. This cluster illustrating cassane-type diterpenes diversity, is composed of 262 nodes, where 137 and 125 nodes are more present in E. ivorense and E. suaveolens, respectively. This cassane-type diterpenes cluster was further divided into three sub-clusters named $A, B$ and $C$ illustrated on Figure $5 \mathrm{~B}$ where principal nodes are labelled by sub-clusters (A, B or C) and a number, example [A1] for node 1 in sub-cluster A.

\subsubsection{Sub-Cluster A}

The first node that we analyzed was more present in E. suaveolens and particularly Sua * samples. It was the one characterized by $m / z 420.2733 \mathrm{RT}=16.97 \mathrm{~min}$ [A1] (Figure 6, Table 2) corresponding to the well-known nor-cassamine or nor-cassamide $[17,26,32,33]$. However, based on the fragmentation pattern described in Figure 4, nor-cassamine was identified. Indeed, the first fragment, $m / z 389.2370$ results from the loss of $\mathrm{CH}_{3} \mathrm{NH}_{2}$.

If the arm was in an amide form, the loss would theoretically be -18.0109 and -32.0262 corresponding to the loss of $\mathrm{H}_{2} \mathrm{O}$ and $\mathrm{CH}_{3} \mathrm{OH}$, respectively (see Supplementary 
Figure S1). Moreover, fragments at $m / z 345.2608\left(\mathrm{M}-\mathrm{C}_{3} \mathrm{H}_{9} \mathrm{NO}\right)$, corresponding to the $N$ -

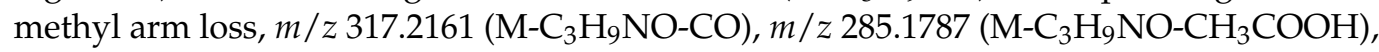
$m / z 267.1682\left(\mathrm{M}-\mathrm{C}_{3} \mathrm{H}_{9} \mathrm{NO}-\mathrm{CH}_{3} \mathrm{COOH}-\mathrm{H}_{2} \mathrm{O}\right)$, and $m / z 257.1853\left(\mathrm{M}^{-} \mathrm{C}_{3} \mathrm{H}_{9} \mathrm{NO}-\mathrm{CH}_{3} \mathrm{COOH}-\right.$ $\mathrm{CO}$ ) (Figure 4) were in accordance with literature [17].

Based on the exact masses and the well-known fragmentation of the substituted 34-cassane-type diterpenes, with the loss of the arm and then the successive losses of the esters in position 4 and then position 3, we were able to propose the other structures. As a matter of fact, a first neighbor to node [A1] with a cosine score (CS) of 0.71 was another more representative compound of Sua *. The node [A2] is characterized by $m / z 406.2569$ $\mathrm{RT}=16.75 \mathrm{~min}$ and corresponds to a new molecule $\mathrm{C}_{23} \mathrm{H}_{35} \mathrm{NO}_{5}(\delta=4.69 \mathrm{ppm})$. In this case, the first fragment observed was $m / z 345.2062$ corresponding to the loss of $\mathrm{C}_{2} \mathrm{H}_{7} \mathrm{NO}$ arm (without $N$-methyl), and the second $m / z 285.1806$, loss of $\mathrm{CH}_{3} \mathrm{COOH}$ as previously described in Figure 4. With this fragmentation pattern, we were not able to define if the arm is linked by an amide or an ester function.

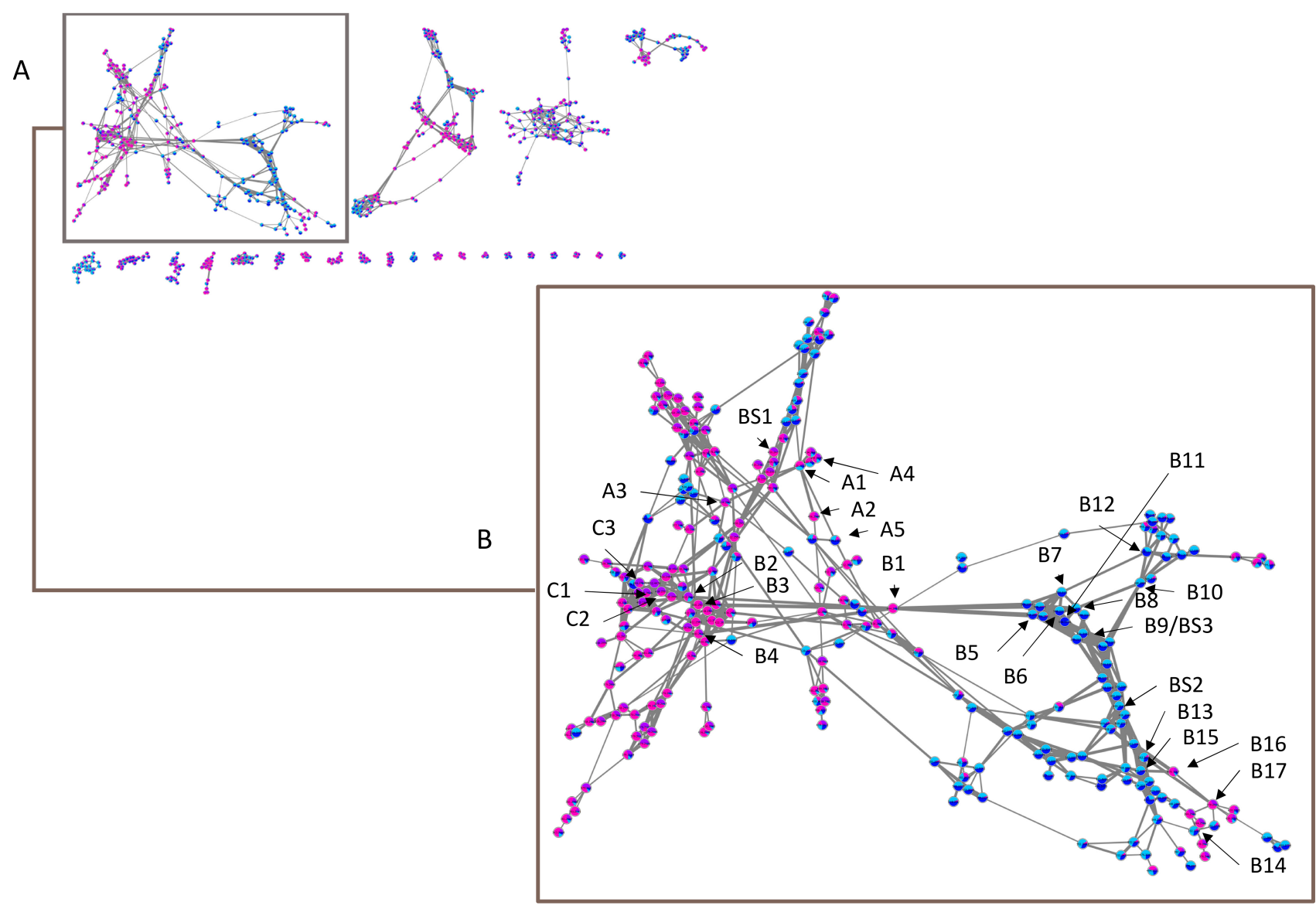

Figure 5. (A) Entire molecular network of Erythrophleum samples and (B) a zoom on cassane-type diterpene network with indications of annotated nodes. Alphanumeric values A, B and C correspond to subclusters mentioned in Table 2 and BS to annotated features assigned by Biosigner algorithm. Pink in nodes represents proportion of Sua *, violet of Ouesso-Sua, light blue of ivo-Libr1 and dark blue of ivo-Libr2 subgroups. 

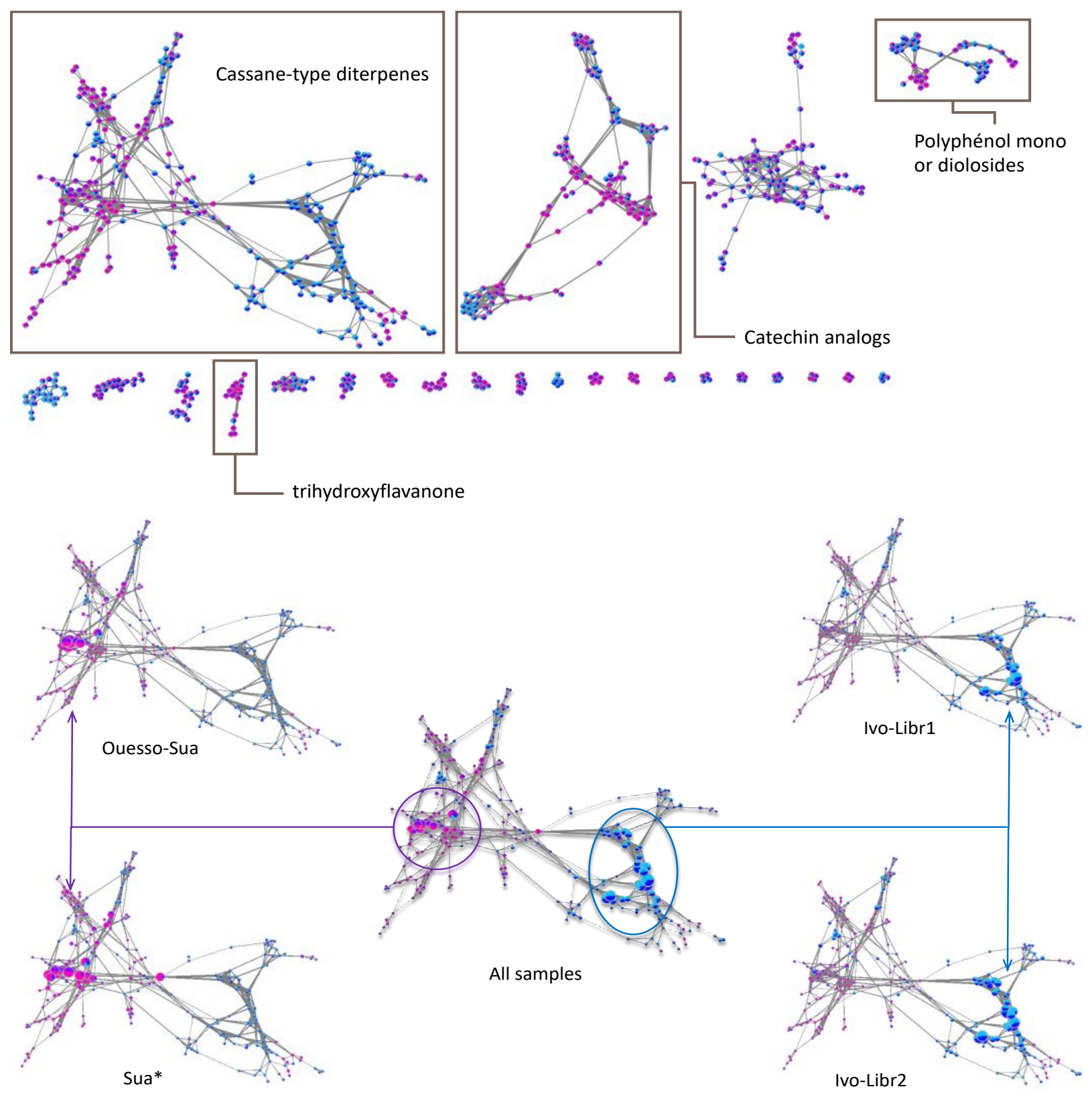

Figure 6. On the (top), attribution of the different sub-clusters using GNPS databases, on the (bottom), focusing on the cassane-type diterpenes cluster where nodes sizes are proportional of the abundances. Each node is a pie-chart with Sua * in pink, Ouesso-Sua in violet, ivo-Libr1 in light blue, ivo-Libr2 in dark blue.

Two other nodes linked to [A1] are more abundant in E. suaveolens (Figure 5), with $m / z 434.2549 \mathrm{RT}=14.53 \mathrm{~min}(\mathrm{CS} 0.72)$ and $m / z 434.2855 \mathrm{RT}=17.16 \mathrm{~min}(\mathrm{CS} 0.72)$ with $\mathrm{C}_{24} \mathrm{H}_{35} \mathrm{NO}_{6}(\delta=2.74 \mathrm{ppm})$ [A3] and $\mathrm{C}_{25} \mathrm{H}_{39} \mathrm{NO}_{5}(\delta=10.59 \mathrm{ppm})$ [A4], respectively. At this collision energy, the first fragments for $\mathrm{C}_{24} \mathrm{H}_{35} \mathrm{NO}_{6}$ [A3] corresponded to $\mathrm{m} / \mathrm{z}$ $403.2047\left(\mathrm{M}-\mathrm{CH}_{3} \mathrm{NH}_{2}\right)$ and $m / z 359.1844\left(\mathrm{M}-\mathrm{C}_{3} \mathrm{H}_{9} \mathrm{NO}\right)$, with the loss of the $N$-methyl arm. The fragments $m / z 299.1598\left(\mathrm{M}-\mathrm{C}_{3} \mathrm{H}_{9} \mathrm{NO}-\mathrm{CH}_{3} \mathrm{COOH}\right)$ and $m / z 281.1675\left(\mathrm{M}-\mathrm{C}_{3} \mathrm{H}_{9} \mathrm{NO}-\right.$ $\mathrm{CH}_{3} \mathrm{COOH}-\mathrm{H}_{2} \mathrm{O}$ ) were also observed and attributed to dehydro-nor-erythrosuamine as previously described in E. suaveolens (synonym: E. guineense [32]) and another Erythrophleum species, E. chlorostachys [32,34]. For $\mathrm{C}_{25} \mathrm{H}_{39} \mathrm{NO}_{5}$ [A4], considering the high CS of 0.74 with [A1], we attributed it to cassamine [31,35-41] that was previously identified in $E$. suaveolens $[17,31,32,42]$. 
In this case, during the fragmentation, we have observed fragments at $m / z 371.2058$ (M-NH( $\left(\mathrm{CH}_{3}\right)_{2}-\mathrm{H}_{2} \mathrm{O}$ ) and $m / z 345.1959$ corresponding to the loss for the dimethyl-amine arm (so an ester form). Fragments $m / z 285.1790\left(\mathrm{M}-\mathrm{C}_{4} \mathrm{H}_{11} \mathrm{NO}-\mathrm{CH}_{3} \mathrm{COOH}\right)$ and then 257.1769 ( $\left.\mathrm{M}-\mathrm{C}_{4} \mathrm{H}_{11} \mathrm{NO}-\mathrm{CH}_{3} \mathrm{COOH}-\mathrm{CO}\right)$ confirmed this possibility.

Interestingly, another node [A5] with CS of 0.63 with [A1], is more present in E. ivorense, and particularly in ivo-Libr 2 with exactly the same fragmentation pattern as [A3]. The molecule [A5] has $m / z 434.2555 \mathrm{RT}=15.76 \mathrm{~min}$, whereas [A3] has $m / z 434.2549$ $\mathrm{RT}=14.43 \mathrm{~min}$.

\subsubsection{Sub-Cluster B}

This cluster (Figure 5, Table 2) is linked with the node [B1] $m / z 494.2757$ RT $=14.44 \mathrm{~min}$, corresponding to $\mathrm{C}_{26} \mathrm{H}_{39} \mathrm{NO}_{8}(\delta=1.74 \mathrm{ppm})$. This molecule was more present in Sua * and is linked to four principal neighbors, three more abundant in E. suaveolens ([B2], [B3] and [B4] with CS of 0.72, 0.82 and 0.78, respectively) and one more present in E. ivorense [B5] with a CS 0.8. The latter is observed four times in the network with similar exact mass, RT and fragmentation patterns and we therefore considered them as only one compound.

For the molecule [B1], a fragment $m / z 363.2301\left(\mathrm{M}-\mathrm{CH}_{3} \mathrm{NH}_{2}\right)$ was first observed before the loss of the $N$-methyl arm, $m / z 419.2012\left(\mathrm{M}-\mathrm{C}_{3} \mathrm{H}_{9} \mathrm{NO}\right)$. Consecutive fragments $m / z$ $401.1922\left(\mathrm{M}-\mathrm{C}_{3} \mathrm{H}_{9} \mathrm{NO}-\mathrm{H}_{2} \mathrm{O}\right), m / z 359.1797\left(\mathrm{M}-\mathrm{C}_{3} \mathrm{H}_{9} \mathrm{NO}-\mathrm{H}_{2} \mathrm{O}-\mathrm{CH}_{3} \mathrm{COOH}\right), m / z$ 299.1569 $\left(\mathrm{M}-\mathrm{C}_{3} \mathrm{H}_{8} \mathrm{NO}-\mathrm{H}_{2} \mathrm{O}-2\left(\mathrm{CH}_{3} \mathrm{COOH}\right)\right), m / z 281.1476\left(\mathrm{M}-\mathrm{C}_{3} \mathrm{H}_{9} \mathrm{NO}-2\left(\mathrm{H}_{2} \mathrm{O}\right)-2\left(\mathrm{CH}_{3} \mathrm{COOH}\right)\right)$ and $m / z 271.1714\left(\mathrm{M}-\mathrm{C}_{3} \mathrm{H}_{9} \mathrm{NO}-\mathrm{H}_{2} \mathrm{O}-2\left(\mathrm{CH}_{3} \mathrm{COOH}\right)-\mathrm{CO}\right)$ were also observed. We do not know if $\mathrm{CO}$ is in position 6 or 7 , but the one in position 6 had already been described in $E$. chlorostachys [43].

In E. suaveolens, the molecule [B2] $\mathrm{m} / \mathrm{z} 452.2664 \mathrm{RT}=12.60 \mathrm{~min}$ corresponds to $\mathrm{C}_{24} \mathrm{H}_{37} \mathrm{NO}_{7}(\delta=4.7 \mathrm{ppm})$ and was attributed to a monoacetylated nor-cassamine; it was more present in Ouesso-Sua. Indeed, fragments at $m / z 421.2293\left(\mathrm{M}_{-} \mathrm{CH}_{3} \mathrm{NH}_{2}\right)$, $m / z 377.1976\left(\mathrm{M}-\mathrm{C}_{3} \mathrm{H}_{9} \mathrm{NO}\right), m / z 359.1824\left(\mathrm{M}-\mathrm{C}_{3} \mathrm{H}_{9} \mathrm{NO}-\mathrm{H}_{2} \mathrm{O}\right), m / z 317.1752$ (M- $\mathrm{C}_{3} \mathrm{H}_{9} \mathrm{NO}-$ $\left.\mathrm{CH}_{3} \mathrm{COOH}\right), m / z 299.1641\left(\mathrm{M}-\mathrm{C}_{3} \mathrm{H}_{9} \mathrm{NO}-\mathrm{CH}_{3} \mathrm{COOH}-\mathrm{H}_{2} \mathrm{O}\right), m / z 271.1709$ (M- $\mathrm{C}_{3} \mathrm{H}_{9} \mathrm{NO}-$ $\mathrm{CH}_{3} \mathrm{COOH}-\mathrm{H}_{2} \mathrm{O}-\mathrm{CO}$ ) and $m / z 253.1540\left(\mathrm{M}-\mathrm{C}_{3} \mathrm{H}_{9} \mathrm{NO}-\mathrm{CH}_{3} \mathrm{COOH}-2 \mathrm{H}_{2} \mathrm{O}-\mathrm{CO}\right)$ were observed. If both ester and amide arm of cassane-type diterpene have been described [39,44-46] however they were never described in E. suaveolens leaves.

Molecule [B3], 480.2607 RT = $14.33 \mathrm{~min}$, corresponding to $\mathrm{C}_{25} \mathrm{H}_{37} \mathrm{NO}_{8}(\delta=7.32 \mathrm{ppm})$ was identified. This molecule has not yet been described in the literature but considering the fragmentation pattern and by comparing with neighbors, it likely has a cassane diterpenoid scaffold [B2] with the same arm as molecule [A2]. Indeed, a first loss of the ester arm was

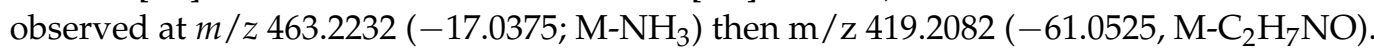
We then observe the following fragments: $m / z 401.1944\left(\mathrm{M}-\mathrm{C}_{2} \mathrm{H}_{7} \mathrm{NO}-\mathrm{H}_{2} \mathrm{O}\right), m / z 359.1776$ $\left(\mathrm{M}-\mathrm{C}_{2} \mathrm{H}_{7} \mathrm{NO}-\mathrm{CH}_{3} \mathrm{COOH}\right), m / z 341.1700\left(\mathrm{M}-\mathrm{C}_{2} \mathrm{H}_{7} \mathrm{NO}-\mathrm{CH}_{3} \mathrm{COOH}-\mathrm{H}_{2} \mathrm{O}\right), m / z \quad 317.1719$ $\left(\mathrm{M}-\mathrm{C}_{2} \mathrm{H}_{7} \mathrm{NO}-\mathrm{CH}_{3} \mathrm{COOH}-\mathrm{H}_{2} \mathrm{O}-\mathrm{CO}\right), m / z 299.1610\left(\mathrm{M}-\mathrm{C}_{2} \mathrm{H}_{7} \mathrm{NO}-2\left(\mathrm{CH}_{3} \mathrm{COOH}\right)\right)$, and $m / z$ $281.1509\left(\mathrm{M}-\mathrm{C}_{2} \mathrm{H}_{7} \mathrm{NO}-2\left(\mathrm{CH}_{3} \mathrm{COOH}\right)-\mathrm{H}_{2} \mathrm{O}\right), m / z 271.1687\left(\mathrm{M}-\mathrm{C}_{2} \mathrm{H}_{7} \mathrm{NO}-2\left(\mathrm{CH}_{3} \mathrm{COOH}\right)-\mathrm{CO}\right)$, and $m / z 253.1555\left(\mathrm{M}-\mathrm{C}_{2} \mathrm{H}_{7} \mathrm{NO}-2\left(\mathrm{CH}_{3} \mathrm{COOH}\right)-\mathrm{CO}-\mathrm{H}_{2} \mathrm{O}\right)$.

The last molecule [B4] of this group has $m / z$ 480.2828 RT $=14.51 \mathrm{~min}$ and corresponds probably to $\mathrm{C}_{25} \mathrm{H}_{37} \mathrm{NO}_{8}(\delta=49 \mathrm{ppm})$. We supposed that this node corresponds to [B3] due to the close retention time. This node probably results from the approximate MZmine processing. Indeed, if we consider the theoretical calculation from the $m / z$ value, the molecular formula is the ester $\mathrm{C}_{22} \mathrm{H}_{41} \mathrm{NO}_{10}(\delta=14.51 \mathrm{ppm})$. No such cassane is described in literature and we cannot manage to further describe it but we believe that a $\mathrm{NH}_{2}$ should occur at the final position as we have the fragment $m / z 419.1992\left(\mathrm{M}-\mathrm{C}_{2} \mathrm{H}_{7} \mathrm{NO}\right)$.

In E. ivorense, molecule [B5] $\mathrm{m} / z$ 508.2980 $\mathrm{RT}=14.40 \mathrm{~min}$, corresponds to $\mathrm{C}_{27} \mathrm{H}_{41} \mathrm{NO}_{8}$ $(\delta=10.64 \mathrm{ppm})$. It was a $N$-methyl-cassaine due to the two fragments at $\mathrm{m} / z 477.2686$ $\left(\mathrm{M}-\mathrm{CH}_{3} \mathrm{NH}_{2}\right)$ and $m / z 433.2176\left(\mathrm{M}-\mathrm{C}_{3} \mathrm{H}_{9} \mathrm{NO}\right)$. Moreover, fragments at $m / z 373.1963$ $\left(\mathrm{M}-\mathrm{C}_{3} \mathrm{H}_{9} \mathrm{NO}-\mathrm{CH}_{3} \mathrm{COOH}\right), m / z 313.1796\left(\left(\mathrm{M}-\mathrm{C}_{3} \mathrm{H}_{9} \mathrm{NO}-2\left(\mathrm{CH}_{3} \mathrm{COOH}\right)\right), m / z 295.1620(\mathrm{M}-\right.$ $\left.\mathrm{C}_{3} \mathrm{H}_{9} \mathrm{NO}-2\left(\mathrm{CH}_{3} \mathrm{COOH}\right)-\mathrm{H}_{2} \mathrm{O}\right), m / z 285.1895\left(\mathrm{M}-\mathrm{C}_{3} \mathrm{H}_{9} \mathrm{NO}-2\left(\mathrm{CH}_{3} \mathrm{COOH}\right)-\mathrm{CO}\right)$, and $m / z$ $267.1718\left(\mathrm{M}-\mathrm{C}_{3} \mathrm{H}_{9} \mathrm{NO}-2\left(\mathrm{CH}_{3} \mathrm{COOH}\right)-\mathrm{CO}-\mathrm{H}_{2} \mathrm{O}\right)$ confirmed this assignment. As a conse- 
quence, molecule [B5] has a typical cassane diterpenoid scaffold with an extra methyl in the diterpenoid scaffold compared to [B1] but no such molecule has been described in literature. Looking closer to neighbors of [B5], we found several molecules with higher molecular masses that were mainly present in E. ivorense.

Molecule [B6], $m / z 548.3212 \mathrm{RT}=17.05 \mathrm{~min}$, corresponding to $\mathrm{C}_{30} \mathrm{H}_{45} \mathrm{NO}_{8}(\delta=1.09 \mathrm{ppm})$, has a similar fragmentation pattern as [B5] with a CS of 0.75. Actually, it was identified as the $3 \beta$-tigloyl derivative with first fragments corresponding to the loss of the arm, leading to $m / z 517.2759\left(\mathrm{M}-\mathrm{CH}_{3} \mathrm{NH}_{2}\right)$ and $m / z 473.2481\left(\mathrm{M}-\mathrm{C}_{3} \mathrm{H}_{9} \mathrm{NO}\right)$. Then, instead of the double losses of $m / z 60.02$ observed for [B5] (losses of two acetic acid), we here observed the loss of one acetic acid $\left(m / z 413.2200 ; \mathrm{M}-\mathrm{C}_{3} \mathrm{H}_{9} \mathrm{NO}-\mathrm{CH}_{3} \mathrm{COOH}\right)$ and the loss of the tigloyl or 3-methylcrotonyl group $\left(\mathrm{m} / \mathrm{z} 313.1709, \mathrm{M}-\mathrm{C}_{3} \mathrm{H}_{9} \mathrm{NO}-\mathrm{CH}_{3} \mathrm{COOH}-\mathrm{CH}_{3} \mathrm{CH}=\mathrm{C}\left(\mathrm{CH}_{3}\right) \mathrm{COOH}\right.$ or $\left.\mathrm{M}-\mathrm{C}_{3} \mathrm{H}_{9} \mathrm{NO}-\mathrm{CH}_{3} \mathrm{COOH}-\left(\mathrm{CH}_{3}\right)_{2} \mathrm{C}=\mathrm{CHCOOH}\right)$.

Molecule [B7], $m / z 550.3350 \mathrm{RT}=17.28 \mathrm{~min}$, corresponding to $\mathrm{C}_{30} \mathrm{H}_{47} \mathrm{NO}_{8}(\delta=4.45 \mathrm{ppm})$, was the reduced form of the $3 \beta$-tigloyl or $3 \beta$-methylcrotonyl derivative. Its fragmentation with the losses of the arm and one acetic acid $\left(m / z 415.2434 ; \mathrm{M}-\mathrm{C}_{3} \mathrm{H}_{9} \mathrm{NO}-\mathrm{CH}_{3} \mathrm{COOH}\right)$ was followed by the loss of the reduced form of tigloyl $\left(\mathrm{m} / \mathrm{z} 313.1745 ; \mathrm{M}_{-} \mathrm{C}_{3} \mathrm{H}_{9} \mathrm{NO}-\right.$ $\mathrm{CH}_{3} \mathrm{COOH}-\mathrm{CH}_{3} \mathrm{CH}_{2} \mathrm{CH}\left(\mathrm{CH}_{3}\right) \mathrm{COOH}$ or $\left.-\left(\mathrm{CH}_{3}\right)_{2} \mathrm{CHCH}_{2} \mathrm{COOH},-102.0689\right)$. As a matter of fact, molecule [B8] with $m / z 566.3312 \mathrm{RT}=14.05 \mathrm{~min}$, corresponding to $\mathrm{C}_{30} \mathrm{H}_{47} \mathrm{NO}_{9}$ $(\delta=2.69 \mathrm{ppm})$, was the hydrate form of molecule [B6] with a hydroxyl group instead of the $3 \beta$-tigloyl or $3 \beta$-methylcrotonyl substitution.

Molecule [B9], $m / z 506.3102 \mathrm{RT}=15.65 \mathrm{~min}$, corresponding to $\mathrm{C}_{28} \mathrm{H}_{43} \mathrm{NO}_{7}(\delta=2.04 \mathrm{ppm})$, was particularly difficult to identify. It is a node neighbor of molecules [B5], [B6] and [B8] (with CS of $0.78,0.76$ and 0.82 , respectively), with $N$-methyl arm as suggested by the fragment $m / z 475.2579\left(\mathrm{M}-\mathrm{CH}_{3} \mathrm{NH}_{2}\right)$ and $m / z 431.2328\left(\mathrm{M}-\mathrm{C}_{3} \mathrm{H}_{9} \mathrm{NO}\right)$. However, no fragment was observed around $m / z 371$, suggesting the absence of an acetoxy in position 4. However, a fragment at $m / z 313.1701\left(\mathrm{M}-\mathrm{C}_{3} \mathrm{H}_{9} \mathrm{NO}-\mathrm{CH}_{3} \mathrm{CH}(\mathrm{OH}) \mathrm{CH}\left(\mathrm{CH}_{3}\right) \mathrm{COOH}\right.$ or $\left.\mathrm{M}-\left(\mathrm{CH}_{3}\right)_{2} \mathrm{CHCH}(\mathrm{OH}) \mathrm{COOH},-118.0627\right)$ suggested the presence of the hydrate form of the $3 \beta$-tigloyl or $3 \beta$-methylcrotonyl. We hypothesized that this molecule was 6-oxocoumingidine previously identified in E. fordii [26].

Molecule [B10], $m / z 488.2988$ RT $15.65 \mathrm{~min}$, corresponding to $\mathrm{C}_{28} \mathrm{H}_{41} \mathrm{NO}_{6}(\delta=3.83 \mathrm{ppm})$, was also related to molecule [B8] with a CS of 0.74 and actually was close to molecule [B9] as it possessed the $N$-methyl arm but the fragments $m / z 413.2240$ and $m / z 313.1663\left(\mathrm{M}-\mathrm{C}_{3} \mathrm{H}_{9} \mathrm{NO}-\right.$ $\mathrm{CH}_{3} \mathrm{COOH}-\mathrm{CH}_{3} \mathrm{CH}=\mathrm{C}\left(\mathrm{CH}_{3}\right) \mathrm{COOH}$ or $\left.\mathrm{M}-\mathrm{C}_{3} \mathrm{H}_{9} \mathrm{NO}-\mathrm{CH}_{3} \mathrm{COOH}-\left(\mathrm{CH}_{3}\right)_{2} \mathrm{C}=\mathrm{CHCOOH}\right)$ suggested the presence of the $3 \beta$-tigloyl or $3 \beta$-methylcrotonyl. It is noteworthy that [B11] is probably an isomer of [B8] as we obtained the same fragmentation pattern with a slightly different RT. Interestingly, [B11] was mainly present in ivo-Libr 2 and is probably a specific feature of this subgroup.

We also found in this cluster B [B12] which is probably a 3-O-glucopyrannosyl deriva-

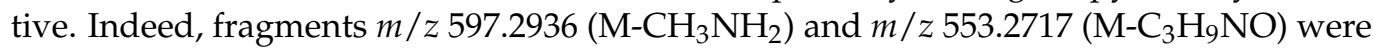
assigned to the $N$-methyl arm. We also observed a fragment $m / z 467.2985(-161.0338$, $\left.\mathrm{M}-\mathrm{C}_{6} \mathrm{H}_{9} \mathrm{O}_{5}\right)$ and a second-high fragment $m / z 331.1976\left(\mathrm{M}-\mathrm{C}_{3} \mathrm{H}_{9} \mathrm{NO}-\mathrm{CH}_{3} \mathrm{COOH}-\mathrm{C}_{6} \mathrm{H}_{10} \mathrm{O}_{5}\right)$ corresponding to the loss of both the 4-acetoxy- and the 3-O-glucopyrannosyl groups. The fragments $m / z 313.1860\left(\left(\mathrm{M}-\mathrm{C}_{3} \mathrm{H}_{9} \mathrm{NO}-\mathrm{CH}_{3} \mathrm{COOH}-\mathrm{C}_{6} \mathrm{H}_{10} \mathrm{O}_{5}-\mathrm{H}_{2} \mathrm{O}\right)\right.$ and $m / z 285.1898$ $\left(\left(\mathrm{M}-\mathrm{C}_{3} \mathrm{H}_{9} \mathrm{NO}-\mathrm{CH}_{3} \mathrm{COOH}-\mathrm{C}_{6} \mathrm{H}_{10} \mathrm{O}_{5}-\mathrm{H}_{2} \mathrm{O}-\mathrm{CO}\right)\right.$ were also observed.

Among other compounds present in E. ivorense, [B13] with $m / z 392.2802 \mathrm{RT}=13.27 \mathrm{~min}$, corresponding to $\mathrm{C}_{23} \mathrm{H}_{37} \mathrm{NO}_{4}(\delta=1.70 \mathrm{ppm})$, is a typical precursor of the cassane-type diterpene with the $N$-methyl arm, nor-cassaine, as suggested by the fragment $m / z 361.2372$ $\left(\mathrm{M}-\mathrm{CH}_{3} \mathrm{NH}_{2}\right)$ and $m / z 317.2101\left(\mathrm{M}-\mathrm{C}_{3} \mathrm{H}_{9} \mathrm{NO}\right)$ and loss of water molecules $(\mathrm{m} / z$ 299.2101; $\mathrm{M}-\mathrm{C}_{3} \mathrm{H}_{9} \mathrm{NO}-\mathrm{H}_{2} \mathrm{O} / \mathrm{m} / \mathrm{z}$ 281.1906; $\left.\mathrm{M}-\mathrm{C}_{3} \mathrm{H}_{9} \mathrm{NO}-2 \mathrm{H}_{2} \mathrm{O}\right)$ or a carbonyl $(\mathrm{m} / \mathrm{z} 289.2144 ; \mathrm{M}-$ $\mathrm{C}_{3} \mathrm{H}_{9} \mathrm{NO}-\mathrm{CO}$ ). The exact same pattern was observed for [B14], $\mathrm{m} / z$ 392.2789 RT = $12.66 \mathrm{~min}$ with the loss of the $N$-methyl arm $\left(m / z 317.2199\left(\mathrm{M}-\mathrm{C}_{3} \mathrm{H}_{9} \mathrm{NO}\right)\right.$ and loss of one water molecule ( $m / z$ 299.2222; $\left.\mathrm{M}-\mathrm{C}_{3} \mathrm{H}_{9} \mathrm{NO}-\mathrm{H}_{2} \mathrm{O}\right)$, a carbonyl $\left(m / z 289.2249 ; \mathrm{M}-\mathrm{C}_{3} \mathrm{H}_{9} \mathrm{NO}-\mathrm{CO}\right)$ or both ( $m / z$ 271.2057; $\left.\mathrm{M}-\mathrm{C}_{3} \mathrm{H}_{9} \mathrm{NO}-\mathrm{CO}-\mathrm{H}_{2} \mathrm{O}\right)$. 
Molecule [B15] is also abundant in E. ivorense and was previously identified as coumingidine in $E$. fordii [26], with $m / z 492.3314 \mathrm{C}_{28} \mathrm{H}_{45} \mathrm{NO}_{6}(\delta=1.15 \mathrm{ppm}) \mathrm{RT}=15.83 \mathrm{~min}$. Indeed, the fragments $m / z 461.2905\left(\mathrm{M}-\mathrm{CH}_{3} \mathrm{NH}_{2}\right.$ ) and $m / z 417.2622\left(\mathrm{M}-\mathrm{C}_{3} \mathrm{H}_{9} \mathrm{NO}\right)$ followed by $m / z 389.2689\left(\mathrm{M}-\mathrm{C}_{3} \mathrm{H}_{9} \mathrm{NO}-\mathrm{CO}\right), m / z 299.2037\left(\mathrm{M}-\mathrm{C}_{3} \mathrm{H}_{9} \mathrm{NO}-\mathrm{CH}_{3} \mathrm{CH}(\mathrm{OH}) \mathrm{CH}\left(\mathrm{CH}_{3}\right) \mathrm{COOH}\right.$ or $\left.-\left(\mathrm{CH}_{3}\right)_{2} \mathrm{CHCH}(\mathrm{OH}) \mathrm{COOH}\right), m / z 281.1868\left(\mathrm{M}-\mathrm{C}_{3} \mathrm{H}_{9} \mathrm{NO}-\mathrm{CH}_{3} \mathrm{CH}(\mathrm{OH}) \mathrm{CH}\left(\mathrm{CH}_{3}\right) \mathrm{COOH}\right.$ or $\left.-\left(\mathrm{CH}_{3}\right)_{2} \mathrm{CHCH}(\mathrm{OH}) \mathrm{COOH}-\mathrm{H}_{2} \mathrm{O}\right), m / z 253.1981\left(\mathrm{M}^{-} \mathrm{C}_{3} \mathrm{H}_{9} \mathrm{NO}-\mathrm{CH}_{3} \mathrm{CH}(\mathrm{OH}) \mathrm{CH}\left(\mathrm{CH}_{3}\right) \mathrm{COOH}\right.$ or - $\left.\left(\mathrm{CH}_{3}\right)_{2} \mathrm{CHCH}(\mathrm{OH}) \mathrm{COOH}-\mathrm{H}_{2} \mathrm{O}-\mathrm{CO}\right)$ were observed. Surprisingly, [B16] was identified as a $\mathrm{C}_{28} \mathrm{H}_{45} \mathrm{NO}_{6} \mathrm{~m} / z 478.3067(\delta=20.1 \mathrm{ppm}) \mathrm{RT}=15.61 \mathrm{~min}$. Mainly present in $E$. suaveolens samples, it is related to [B15] and only differs by the presence of a primary amine on the arm. Indeed, the first loss was the amine arm $\left(m / z\right.$ 417.2685; $\left.\mathrm{M}-\mathrm{C}_{2} \mathrm{H}_{7} \mathrm{NO}\right)$ followed by the loss of the $3 \beta$-hydroxytigloyl or $3 \beta$-hydroxyméthylcrotonyl $(m / z 299.2079$; $\mathrm{M}-\mathrm{C}_{2} \mathrm{H}_{7} \mathrm{NO}-\mathrm{CH}_{3} \mathrm{CH}(\mathrm{OH}) \mathrm{CH}\left(\mathrm{CH}_{3}\right) \mathrm{COOH}$ or $\left.-\left(\mathrm{CH}_{3}\right)_{2} \mathrm{CHCH}(\mathrm{OH}) \mathrm{COOH}-\mathrm{H}_{2} \mathrm{O}\right)$.

Molecule [B17],$m / z 378.2625 \mathrm{RT}=13.10 \mathrm{~min}$, corresponding to $\mathrm{C}_{22} \mathrm{H}_{35} \mathrm{NO}_{4}(\delta=3.67 \mathrm{ppm})$ was identified as a new compound. Beside the neutral loss of $\mathrm{NH}_{3}\left(\mathrm{~m} / z\right.$ 361.2242, $\left.\mathrm{M}-\mathrm{NH}_{3}\right)$ and loss of the amine arm $\left(\mathrm{m} / z\right.$ 317.2155; $\mathrm{M}-\mathrm{C}_{2} \mathrm{H}_{7} \mathrm{NO}$ ), fragments at $m / z 299.2056$ (M$\left.\mathrm{C}_{2} \mathrm{H}_{7} \mathrm{NO}-\mathrm{H}_{2} \mathrm{O}\right), m / z 281.2047\left(\mathrm{M}-\mathrm{C}_{2} \mathrm{H}_{7} \mathrm{NO}-2 \mathrm{H}_{2} \mathrm{O}\right)$ and $m / z 271.2099\left(\mathrm{M}-\mathrm{M}_{-} \mathrm{C}_{2} \mathrm{H}_{7} \mathrm{NO}-\mathrm{H}_{2} \mathrm{O}-\right.$ $\mathrm{CO})$ were also observed. We hypothesized that [B17] is a demethylated cassaine which was mainly present in E. suaveolens.

\subsubsection{Sub-Cluster C}

Finally, a subgroup of compounds was mainly expressed in Ouesso-Sua. The compound [C2] with a $m / z 452.4476 \mathrm{RT}=11.17 \mathrm{~min}$ had a low abundance and the structure was not determined. However, several compounds in this zone are cassane diterpenes, for example, [C1], $\mathrm{m} / z 452.2636 \mathrm{RT}=11.17 \mathrm{~min}$ is $\mathrm{C}_{24} \mathrm{H}_{37} \mathrm{NO}_{7}(\delta=1.50 \mathrm{ppm})$. Fragments of [C1] $m / z 421.2360\left(\mathrm{M}-\mathrm{CH}_{3} \mathrm{NH}_{2}\right)$ and $m / z 377.1924\left(\mathrm{M}-\mathrm{C}_{3} \mathrm{H}_{9} \mathrm{NO}\right)$ were at-

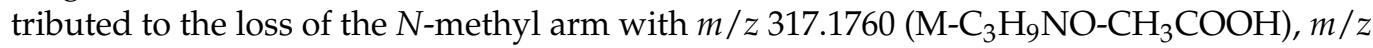
$299.1617\left(\mathrm{M}-\mathrm{C}_{3} \mathrm{H}_{9} \mathrm{NO}-\mathrm{CH}_{3} \mathrm{COOH}-\mathrm{H}_{2} \mathrm{O}\right), m / z 281.1528\left(\mathrm{M}^{-} \mathrm{C}_{3} \mathrm{H}_{9} \mathrm{NO}-\mathrm{CH}_{3} \mathrm{COOH}-2 \mathrm{H}_{2} \mathrm{O}\right)$, $m / z 271.1644\left(\mathrm{M}-\mathrm{C}_{3} \mathrm{H}_{9} \mathrm{NO}-\mathrm{CH}_{3} \mathrm{COOH}-\mathrm{H}_{2} \mathrm{O}-\mathrm{CO}\right), m / z 253.1600\left(\mathrm{M}^{-} \mathrm{C}_{3} \mathrm{H}_{9} \mathrm{NO}-\mathrm{CH}_{3} \mathrm{COOH}-\right.$ $2 \mathrm{H}_{2} \mathrm{O}-\mathrm{CO}$ ). This compound was an isomer of [B2]. A neighbor of [C1] is [C2], $m / z 438.2501$ $\mathrm{RT}=10.97 \mathrm{~min}$ is $\mathrm{C}_{23} \mathrm{H}_{35} \mathrm{NO}_{7}$ ( $\delta=3.36 \mathrm{ppm}$ ), was a demethylated form of [C1]. Indeed, $m / z 377.1923\left(\mathrm{M}_{-} \mathrm{C}_{2} \mathrm{H}_{7} \mathrm{NO}\right)$ were attributed to the loss of the amine arm while $m / z 317.1731$ $\left(\mathrm{M}-\mathrm{C}_{2} \mathrm{H}_{7} \mathrm{NO}-\mathrm{CH}_{3} \mathrm{COOH}\right), m / z 299.1594\left(\mathrm{M}-\mathrm{C}_{2} \mathrm{H}_{7} \mathrm{NO}-\mathrm{CH}_{3} \mathrm{COOH}-\mathrm{H}_{2} \mathrm{O}\right), m / z 281.1534$ (M- $\left.\mathrm{C}_{2} \mathrm{H}_{7} \mathrm{NO}-\mathrm{CH}_{3} \mathrm{COOH}-2 \mathrm{H}_{2} \mathrm{O}\right), m / z 271.1695\left(\mathrm{M}-\mathrm{C}_{2} \mathrm{H}_{7} \mathrm{NO}-\mathrm{CH}_{3} \mathrm{COOH}-\mathrm{H}_{2} \mathrm{O}-\mathrm{CO}\right)$. A final compound that illustrate the sub-cluster $\mathrm{C}$ is [C3], $\mathrm{m} / \mathrm{z} 466.2787 \mathrm{RT}=11.31 \mathrm{~min}$ is $\mathrm{C}_{25} \mathrm{H}_{39} \mathrm{NO}_{7}(\delta=2.64 \mathrm{ppm})$, was a $\mathrm{N}, \mathrm{N}$-dimethylamine form of [C1]. Indeed, fragments $m / z 421.2158\left(\mathrm{M}-\left(\mathrm{CH}_{3}\right)_{2} \mathrm{NH}\right)$ and $m / z 377.2053\left(\mathrm{M}-\mathrm{C}_{4} \mathrm{H}_{11} \mathrm{NO}\right)$ were attributed to the loss of the $\mathrm{N}, \mathrm{N}$-dimethyl arm. Then, fragments could also be attributed including $\mathrm{m} / z 317.1684$ $\left(\mathrm{M}-\mathrm{C}_{4} \mathrm{H}_{11} \mathrm{NO}-\mathrm{CH}_{3} \mathrm{COOH}\right), m / z 299.1638\left(\mathrm{M}-\mathrm{C}_{4} \mathrm{H}_{11} \mathrm{NO}-\mathrm{CH}_{3} \mathrm{COOH}-\mathrm{H}_{2} \mathrm{O}\right), m / z 281.1534$ $\left(\mathrm{M}-\mathrm{C}_{2} \mathrm{H}_{7} \mathrm{NO}-\mathrm{CH}_{3} \mathrm{COOH}-2 \mathrm{H}_{2} \mathrm{O}\right), m / z 271.1695\left(\mathrm{M}-\mathrm{C}_{2} \mathrm{H}_{7} \mathrm{NO}-\mathrm{CH}_{3} \mathrm{COOH}-\mathrm{H}_{2} \mathrm{O}-\mathrm{CO}\right)$.

\subsubsection{Other Networks}

The molecular network analysis had also emphasized the diversity of polyphenol derivatives (Figure 6). Based on GNPS analogs search [47-50], catechin derivatives for 2nd cluster and flavonoid-glycosides for 4th cluster were mainly observed in Sua*. In contrast, quercetin derivatives were observed in ivo-Libr 1 for 4 th cluster. Finally, a trihydroxyflavanone derivative was particularly present in E. suaveolens for 8th cluster (framed in Figure 6).

\subsection{Species-Specific Metabolite Features and Identification}

Biosigner analysis was performed on W4M to determine which features have significantly different abundances in the two species (ivo and sua), in order to identify species-specific metabolites. Two ions were highlighted according to a minimum of two of the three distinct classifier algorithms (PLS-DA, RF, and SVM methods). This metabolomics variable selection evaluated the relevance of the variables for the pre- 
diction performances of the classifier [51]. Three features highlighted in Figure 4 were kept: [BS1] had a $m / z 450.2492$ and $\mathrm{RT}=13.21 \mathrm{~min}$ and was a marker of E. suaveolens. Based on the molecular network, the putative cassane-type diterpenes molecular formula was $\mathrm{C}_{24} \mathrm{H}_{35} \mathrm{NO}_{7}(\delta=2.07 \mathrm{ppm})$ and we assigned this molecule to $3 \beta$-hydroxy-4-acetoxy6-oxo-nor-cassamine. Actually, we were able to observe the following fragments $\mathrm{m} / \mathrm{z}$ $419.2053\left(\mathrm{M}-\mathrm{CH}_{3} \mathrm{NH}_{2}\right), m / z 375.1831\left(\mathrm{M}-\mathrm{C}_{3} \mathrm{H}_{9} \mathrm{NO}\right), m / z 357.1632\left(\mathrm{M}-\mathrm{C}_{3} \mathrm{H}_{9} \mathrm{NO}-\mathrm{H}_{2} \mathrm{O}\right), m / z$ $315.1587\left(\mathrm{M}-\mathrm{C}_{3} \mathrm{H}_{9} \mathrm{NO}-\mathrm{CH}_{3} \mathrm{COOH}\right), \mathrm{m} / z 297.1476\left(\mathrm{M}-\mathrm{C}_{3} \mathrm{H}_{9} \mathrm{NO}-\mathrm{CH}_{3} \mathrm{COOH}-\mathrm{H}_{2} \mathrm{O}\right)$, and $m / z$

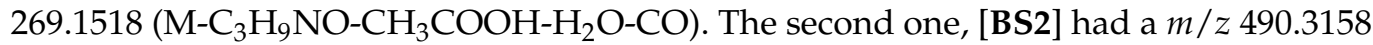
and $\mathrm{RT}=19.28 \mathrm{~min}$ and was a marker of $E$. ivorense with a putative formula $\mathrm{C}_{28} \mathrm{H}_{43} \mathrm{NO}_{6}$ $(\delta=1.05 \mathrm{ppm})$. As described before, we have noticed that several molecules in E. ivorense (called "heavy cassanes") have higher molecular weights than the ones in E. suaveolens. Fragments $m / z 459.2685\left(\mathrm{M}-\mathrm{CH}_{3} \mathrm{NH}_{2}\right), m / z 415.2507\left(\mathrm{M}-\mathrm{C}_{3} \mathrm{H}_{9} \mathrm{NO}\right), m / z 315.1960$ (M$\mathrm{C}_{3} \mathrm{H}_{9} \mathrm{NO}-\mathrm{CH}_{3} \mathrm{CH}=\mathrm{C}\left(\mathrm{CH}_{3}\right) \mathrm{COOH}$ or $\left.\mathrm{M}-\mathrm{C}_{3} \mathrm{H}_{9} \mathrm{NO}-\left(\mathrm{CH}_{3}\right)_{2} \mathrm{C}=\mathrm{CHCOOH}\right), \mathrm{m} / z 297.1834$ (M$\mathrm{C}_{3} \mathrm{H}_{9} \mathrm{NO}-\mathrm{CH}_{3} \mathrm{CH}=\mathrm{C}\left(\mathrm{CH}_{3}\right) \mathrm{COOH}-\mathrm{H}_{2} \mathrm{O}$ or $\left.\mathrm{M}-\mathrm{C}_{3} \mathrm{H}_{9} \mathrm{NO}-\left(\mathrm{CH}_{3}\right)_{2} \mathrm{C}=\mathrm{CHCOOH}-\mathrm{H}_{2} \mathrm{O}\right), m / z$ $279.1725\left(\mathrm{M}-\mathrm{C}_{3} \mathrm{H}_{9} \mathrm{NO}-\mathrm{CH}_{3} \mathrm{CH}=\mathrm{C}\left(\mathrm{CH}_{3}\right) \mathrm{COOH}-2 \mathrm{H}_{2} \mathrm{O}\right.$ or $\mathrm{M}-\mathrm{C}_{3} \mathrm{H}_{9} \mathrm{NO}-\left(\mathrm{CH}_{3}\right)_{2} \mathrm{C}=\mathrm{CHCOOH}-$ $\left.2 \mathrm{H}_{2} \mathrm{O}\right)$, and $m / z 269.1873\left(\mathrm{M}-\mathrm{C}_{3} \mathrm{H}_{9} \mathrm{NO}-\mathrm{CH}_{3} \mathrm{CH}=\mathrm{C}\left(\mathrm{CH}_{3}\right) \mathrm{COOH}-\mathrm{H}_{2} \mathrm{O}-\mathrm{CO}\right.$ or $\mathrm{M}-\mathrm{C}_{3} \mathrm{H}_{9} \mathrm{NO}-$ $\left.\left(\mathrm{CH}_{3}\right)_{2} \mathrm{C}=\mathrm{CHCOOH}-\mathrm{H}_{2} \mathrm{O}-\mathrm{CO}\right)$ allowed us to assign this molecule to the structure $3 \beta$-tigloyl or $3 \beta$-methylcrotonyl-6-hydroxy-nor-cassamine, a heavy cassane diterpene specifically found in E. ivorense. The third one, [BS3] had a $\mathrm{m} / z 506.3113$ and RT $=16.31 \mathrm{~min}$ with a putative structure of $\mathrm{C}_{28} \mathrm{H}_{43} \mathrm{NO}_{7}(\delta=0.14 \mathrm{ppm})$. It is the same compound as [B9] and was accordingly assigned as a $3 \beta$-hydroxytigloyl or $3 \beta$-hydroxymethylcrotonyl-6-oxo-norcassamine, another heavy cassane diterpenoid found in E. ivorense. 


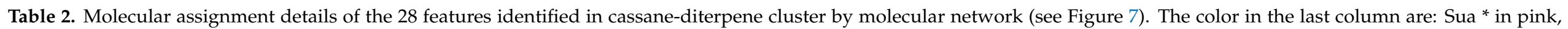
Ouesso-Sua in violet, ivo-Libr1 in light blue, ivo-Libr2 in dark blue as in Figures 5 and 6.

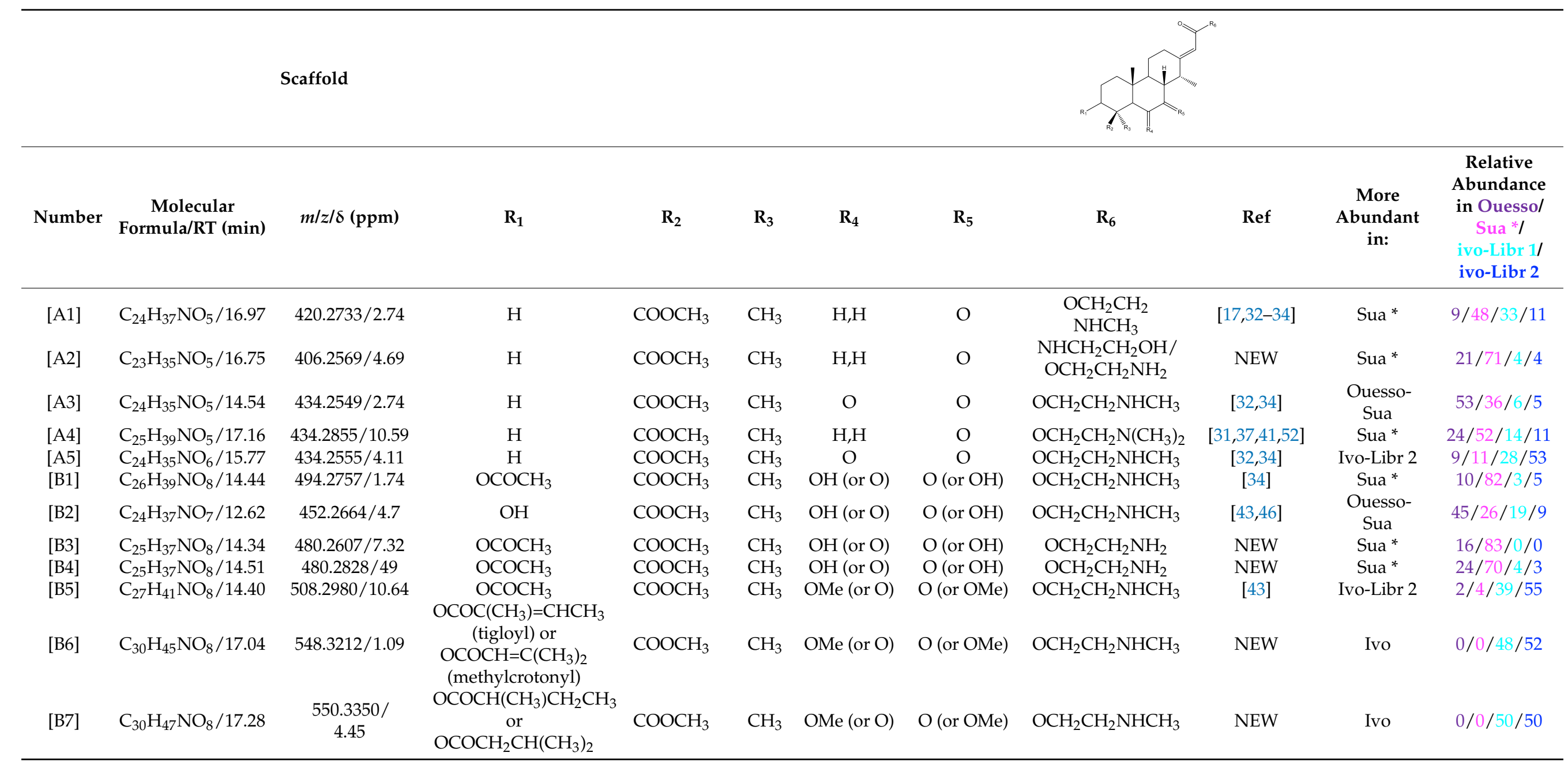


Table 2. Cont.

\begin{tabular}{|c|c|c|c|c|c|c|c|c|c|c|c|}
\hline & & Scaffold & & & & & & & & & \\
\hline Number & $\begin{array}{c}\text { Molecular } \\
\text { Formula/RT (min) }\end{array}$ & $m / z / \delta(\mathrm{ppm})$ & $\mathbf{R}_{1}$ & $\mathbf{R}_{2}$ & $\mathbf{R}_{3}$ & $\mathbf{R}_{4}$ & $\mathbf{R}_{5}$ & $\mathbf{R}_{6}$ & Ref & $\begin{array}{l}\text { More } \\
\text { Abundant } \\
\text { in: }\end{array}$ & $\begin{array}{c}\text { Relative } \\
\text { Abundance } \\
\text { in Ouesso/ } \\
\text { Sua */ } \\
\text { ivo-Libr 1/ } \\
\text { ivo-Libr } 2\end{array}$ \\
\hline [B8] & $\mathrm{C}_{30} \mathrm{H}_{47} \mathrm{NO}_{9} / 14.05$ & $\begin{array}{c}566.3312 / \\
2.69\end{array}$ & $\begin{array}{c}\mathrm{OCOC}(\mathrm{OH})\left(\mathrm{CH}_{3}\right) \\
\mathrm{CH}_{2} \mathrm{CH}_{3} \text { or } \\
\mathrm{OCOCH}(\mathrm{OH}) \\
\mathrm{CH}\left(\mathrm{CH}_{3}\right)_{2} \\
\mathrm{OCOC}(\mathrm{OH})\left(\mathrm{CH}_{2}\right)\end{array}$ & $\mathrm{COOCH}_{3}$ & $\mathrm{CH}_{3}$ & OMe (or O) & $\mathrm{O}$ (or OMe) & $\mathrm{OCH}_{2} \mathrm{CH}_{2} \mathrm{NHCH}_{3}$ & NEW & Ivo & $0 / 1 / 51 / 48$ \\
\hline [B9] & $\mathrm{C}_{28} \mathrm{H}_{43} \mathrm{NO}_{7} / 15.65$ & $\begin{array}{l}506.3102 / \\
2.04\end{array}$ & $\begin{array}{c}\mathrm{CH}_{2} \mathrm{CH}_{3} \text { or } \\
\mathrm{OCOCH}(\mathrm{OH}) \\
\mathrm{CH}\left(\mathrm{CH}_{3}\right)_{2}\end{array}$ & $\mathrm{CH}_{3}$ & $\mathrm{CH}_{3}$ & $\mathrm{O}$ & $\mathrm{O}$ & $\mathrm{OCH}_{2} \mathrm{CH}_{2} \mathrm{NHCH}_{3}$ & NEW & Ivo & $0 / 0 / 52 / 48$ \\
\hline [B10] & $\mathrm{C}_{28} \mathrm{H}_{41} \mathrm{NO}_{6} / 17.87$ & $\begin{array}{c}488.2988 / \\
3.83\end{array}$ & $\begin{array}{c}\mathrm{OCOC}\left(\mathrm{CH}_{3}\right)=\mathrm{CHCH}_{3} \\
\text { or } \\
\text { OCOCH}=\mathrm{C}\left(\mathrm{CH}_{3}\right)_{2} \\
\mathrm{OCOC}(\mathrm{OH})\left(\mathrm{CH}_{3}\right)\end{array}$ & $\mathrm{CH}_{3}$ & $\mathrm{CH}_{3}$ & $\mathrm{O}$ & $\mathrm{O}$ & $\mathrm{OCH}_{2} \mathrm{CH}_{2} \mathrm{NHCH}_{3}$ & NEW & Ivo-Libr 1 & $1 / 1 / 59 / 39$ \\
\hline [B11] & $\mathrm{C}_{30} \mathrm{H}_{48} \mathrm{NO}_{9} / 14.17$ & $566.3308 / 2.76$ & $\begin{array}{c}\mathrm{CH}_{2} \mathrm{CH}_{3} \text { or } \\
\mathrm{OCOCH}(\mathrm{OH}) \\
\mathrm{CH}\left(\mathrm{CH}_{3}\right)_{2}\end{array}$ & $\mathrm{COOCH}_{3}$ & $\mathrm{CH}_{3}$ & $\mathrm{OMe}($ or $\mathrm{O}$ ) & $\mathrm{O}$ (or OMe) & $\mathrm{OCH}_{2} \mathrm{CH}_{2} \mathrm{NHCH}_{3}$ & NEW & Ivo-Libr 2 & $1 / 1 / 3 / 95$ \\
\hline [B12] & $\mathrm{C}_{31} \mathrm{H}_{49} \mathrm{NO}_{12} / 10.40$ & $628.3323 / 0.72$ & O-glucopyrannosyl & $\mathrm{COOCH}_{3}$ & $\mathrm{CH}_{3}$ & OMe (or O) & $\mathrm{O}$ (or OMe) & $\mathrm{OCH}_{2} \mathrm{CH}_{2} \mathrm{NHCH}_{3}$ & NEW & Ivo-Libr 2 & $1 / 0 / 35 / 65$ \\
\hline [B13] & $\mathrm{C}_{23} \mathrm{H}_{37} \mathrm{NO}_{4} / 13.27$ & $392.2802 / 1.70$ & $\mathrm{OH}$ & $\mathrm{CH}_{3}$ & $\mathrm{CH}_{3}$ & $\mathrm{H}, \mathrm{H}$ & $\mathrm{O}$ & $\mathrm{OCH}_{2} \mathrm{CH}_{2} \mathrm{NHCH}_{3}$ & NEW & Ivo-Libr 1 & $4 / 7 / 63 / 27$ \\
\hline$[\mathrm{B} 14]$ & $\mathrm{C}_{23} \mathrm{H}_{37} \mathrm{NO}_{4} / 12.66$ & $392.2789 / 1.62$ & $\mathrm{OH}$ & $\mathrm{CH}_{3}$ & $\mathrm{CH}_{3}$ & $\mathrm{O}$ & $\mathrm{H}, \mathrm{H}$ & $\mathrm{OCH}_{2} \mathrm{CH}_{2} \mathrm{NHCH}_{3}$ & NEW & Ivo-Libr1 & $5 / 6 / 62 / 27$ \\
\hline [B15] & $\mathrm{C}_{28} \mathrm{H}_{45} \mathrm{NO}_{6} / 15.83$ & $492.3314 / 1.15$ & $\begin{array}{c}\mathrm{CH}_{2} \mathrm{CH}_{3} \text { or } \\
\mathrm{OCOCH}(\mathrm{OH}) \\
\mathrm{CH}\left(\mathrm{CH}_{3}\right)_{2} \mathrm{OCOCH} \mathrm{CH}_{2} \mathrm{C} \\
(\mathrm{OH})\left(\mathrm{CH}_{3}\right)_{2}\end{array}$ & $\mathrm{CH}_{3}$ & $\mathrm{CH}_{3}$ & $\mathrm{H}, \mathrm{H}$ & $\mathrm{O}$ & $\mathrm{OCH}_{2} \mathrm{CH}_{2} \mathrm{NHCH}_{3}$ & [26] & Ivo-Libr1 & $1 / 3 / 53 / 43$ \\
\hline
\end{tabular}


Table 2. Cont.

\begin{tabular}{|c|c|c|c|c|c|c|c|c|c|c|c|}
\hline & & Scaffold & & & & & & 4 & & & \\
\hline Number & $\begin{array}{c}\text { Molecular } \\
\text { Formula/RT (min) }\end{array}$ & m/z/ठ (ppm) & $\mathbf{R}_{\mathbf{1}}$ & $\mathbf{R}_{2}$ & $\mathbf{R}_{3}$ & $\mathbf{R}_{4}$ & $\mathbf{R}_{5}$ & $\mathbf{R}_{6}$ & Ref & $\begin{array}{l}\text { More } \\
\text { Abundant } \\
\text { in: }\end{array}$ & $\begin{array}{c}\text { Relative } \\
\text { Abundance } \\
\text { in Ouesso/ } \\
\text { Sua */ } \\
\text { ivo-Libr 1/ } \\
\text { ivo-Libr } 2 \\
\end{array}$ \\
\hline [B16] & $\mathrm{C}_{27} \mathrm{H}_{43} \mathrm{NO}_{6} / 15.61$ & $478.3067 / 20.1$ & $\begin{array}{c}\mathrm{OCOC}(\mathrm{OH})\left(\mathrm{CH}_{3}\right) \\
\mathrm{CH}_{2} \mathrm{CH}_{3} \text { or } \\
\mathrm{OCOCH}_{(\mathrm{OH})} \\
\mathrm{CH}\left(\mathrm{CH}_{3}\right)_{2} \mathrm{OCOCH}_{2} \mathrm{C} \\
(\mathrm{OH})\left(\mathrm{CH}_{3}\right)_{2}\end{array}$ & $\mathrm{CH}_{3}$ & $\mathrm{CH}_{3}$ & $\mathrm{H}, \mathrm{H}$ & $\mathrm{O}$ & $\mathrm{OCH}_{2} \mathrm{CH}_{2} \mathrm{NH}_{2}$ & NEW & Sua * & $21 / 61 / 7 / 11$ \\
\hline [B17] & $\mathrm{C}_{22} \mathrm{H}_{35} \mathrm{NO}_{4} / 13.10$ & $378.2625 / 3.67$ & $\mathrm{OH}$ & $\mathrm{CH}_{3}$ & $\mathrm{CH}_{3}$ & $\mathrm{H}, \mathrm{H}$ & $\mathrm{O}($ or $\mathrm{OH})$ & $\mathrm{OCH}_{2} \mathrm{CH}_{2} \mathrm{NH}_{2}$ & NEW & Sua * & $33 / 62 / 3 / 2$ \\
\hline [C1] & $\mathrm{C}_{24} \mathrm{H}_{37} \mathrm{NO}_{7} / 11.17$ & $452.2636 / 1.50$ & $\mathrm{OH}$ & $\mathrm{COOCH}_{3}$ & $\mathrm{CH}_{3}$ & $\mathrm{OH}($ or $\mathrm{O})$ & $\mathrm{O}($ or $\mathrm{OH})$ & $\mathrm{OCH}_{2} \mathrm{CH}_{2} \mathrm{NHCH}_{3}$ & {$[43,46]$} & $\begin{array}{l}\text { Ouesso- } \\
\text { Sua }\end{array}$ & $60 / 36 / 1 / 3$ \\
\hline [C2] & $\mathrm{C}_{23} \mathrm{H}_{35} \mathrm{NO}_{7} / 10.97$ & $438.2501 / 3.36$ & $\mathrm{OH}$ & $\mathrm{COOCH}_{3}$ & $\mathrm{CH}_{3}$ & $\mathrm{OH}($ or $\mathrm{O})$ & $\mathrm{O}($ or $\mathrm{OH})$ & $\mathrm{OCH}_{2} \mathrm{CH}_{2} \mathrm{NH}_{2}$ & NEW & $\begin{array}{l}\text { Ouesso- } \\
\text { Sua }\end{array}$ & $60 / 40 / 0 / 0$ \\
\hline [C3] & $\mathrm{C}_{25} \mathrm{H}_{39} \mathrm{NO}_{7} / 11.31$ & $466.2787 / 2.64$ & $\mathrm{OH}$ & $\mathrm{COOCH}_{3}$ & $\mathrm{CH}_{3}$ & $\mathrm{OH}($ or $\mathrm{O})$ & $\mathrm{O}($ or $\mathrm{OH})$ & $\mathrm{OCH}_{2} \mathrm{CH}_{2} \mathrm{NH}\left(\mathrm{CH}_{3}\right)_{2}$ & NEW & $\begin{array}{l}\text { Ouesso- } \\
\text { Sua }\end{array}$ & $69 / 24 / 2 / 5$ \\
\hline [BS1] & $\mathrm{C}_{24} \mathrm{H}_{35} \mathrm{NO}_{7} / 12.84$ & $\begin{array}{c}450.2477 / 1.27 \\
\text { (Biosigner } \\
450.2492 / 2.07)\end{array}$ & $\mathrm{OH}$ & $\mathrm{COOCH}_{3}$ & $\mathrm{CH}_{3}$ & $\mathrm{O}$ & $\mathrm{O}$ & $\mathrm{OCH}_{2} \mathrm{CH}_{2} \mathrm{NHCH}_{3}$ & NEW & Sua * & $40 / 59 / 0 / 1$ \\
\hline [BS2] & $\mathrm{C}_{28} \mathrm{H}_{43} \mathrm{NO}_{6} / 18.48$ & $\begin{array}{c}490.3145 / 3.71 \\
\text { (Biosigner } \\
490.3158 / 1.05)\end{array}$ & $\begin{array}{c}\mathrm{OCOC}\left(\mathrm{CH}_{3}\right)=\mathrm{CHCH}_{3} \\
\text { or } \\
\mathrm{OCOCH}=\mathrm{C}\left(\mathrm{CH}_{3}\right)_{2}\end{array}$ & $\mathrm{CH}_{3}$ & $\mathrm{CH}_{3}$ & $\mathrm{OH}($ or $\mathrm{O})$ & $\mathrm{O}($ or $\mathrm{OH})$ & $\mathrm{OCH}_{2} \mathrm{CH}_{2} \mathrm{NHCH}_{3}$ & NEW & Ivo-Libr 1 & $0 / 0 / 65 / 35$ \\
\hline [BS3] & $\mathrm{C}_{28} \mathrm{H}_{43} \mathrm{NO}_{7} / 15.65$ & $\begin{array}{c}506.3102 / 2.04 \\
\quad(\text { Biosigner } \\
506.3113 / 0.14)\end{array}$ & $\begin{array}{c}\mathrm{OCOC}(\mathrm{OH})\left(\mathrm{CH}_{3}\right) \\
\mathrm{CH}_{2} \mathrm{CH}_{3} \text { or } \\
\mathrm{OCOCH}(\mathrm{OH}) \\
\mathrm{CH}\left(\mathrm{CH}_{3}\right)_{2}\end{array}$ & $\mathrm{CH}_{3}$ & $\mathrm{CH}_{3}$ & $\mathrm{O}$ & $\mathrm{O}$ & $\mathrm{OCH}_{2} \mathrm{CH}_{2} \mathrm{NHCH}_{3}$ & NEW & Ivo & $0 / 0 / 52 / 48$ \\
\hline
\end{tabular}




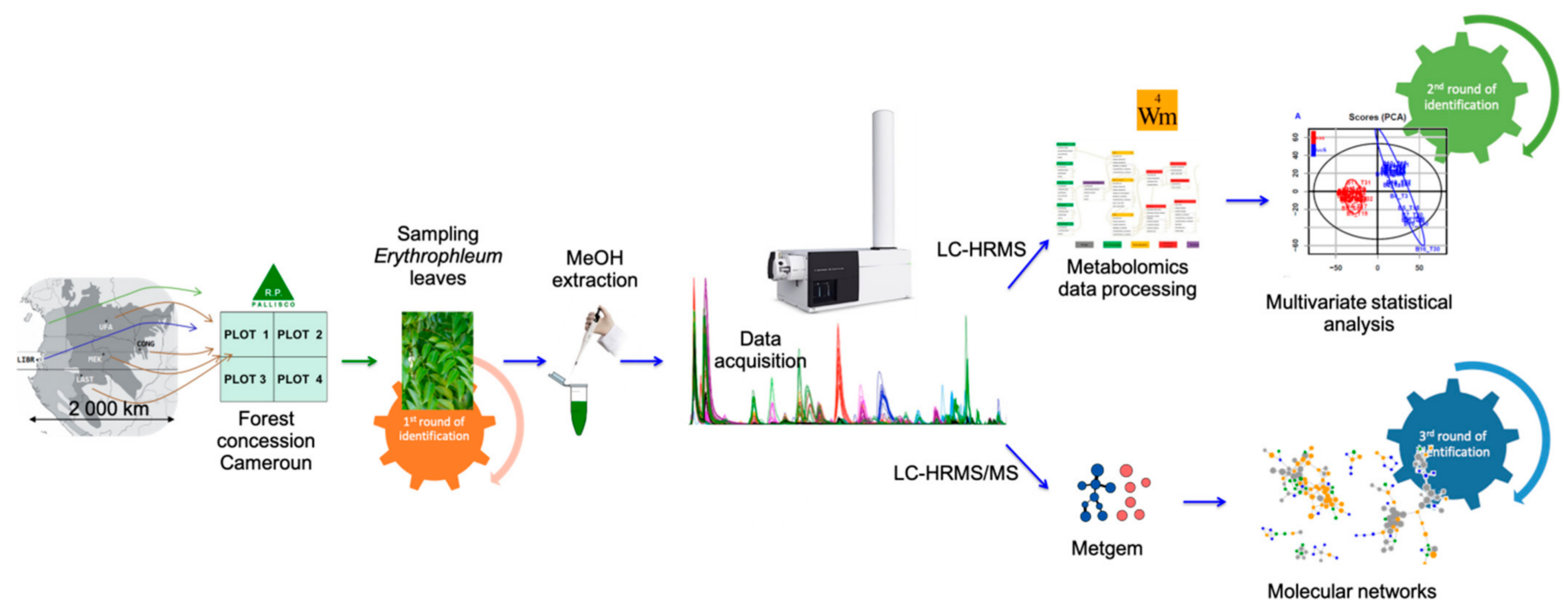

Figure 7. Experimental sampling design and overview of the workflow followed for metabolomics analysis of Erythrophleum leaves. E. suaveolens and E. ivorense from five populations were grown in 4 plots in a forest concession in Cameroon. Leaves of 44 trees were sampled, air-dried and metabolites were extracted with methanol $(\mathrm{MeOH})$. Liquid chromatography coupled to electrospray ionization high-resolution mass spectrometry (LC-ESI-HRMS(/MS)) was performed to characterize the metabolome diversity. Data analysis was completed by exploration using molecular networking.

\section{Discussion}

The use of plants by human populations has an important chemical aspect, which can mediate complex people-plant relationships [42]. The perennial plants of Erythrophleum genus are being threatened by over-exploitation due to their critical roles in the medicinal applications (in particular for E. fordii and E. lasianthum), especially for their high content of cardiac alkaloids [20].

We studied this wild plant, which man has not influenced a priori by cultivation or other selections and used samples from different origins but grown in a common garden experiment to minimize metabolomics differences due to environmental effects. We have assembled a homogeneous pool of 44 mature leaf samples from two species of Erythrophleum (E. ivorense 23 samples, E. suaveolens 21 samples). This wild plant naturally grows in tropical Africa and the two focal species are difficult to identify in the field due to their morphological similarity.

Our untargeted metabolomics investigation obviously discriminates the species (Figure 2A) but we were also able to discriminate intra-specific variations, i.e., geographical origins (Figure 2B). Species discrimination was expected and the clustering of populations of $E$. ivorense and E. suaveolens is obvious even if botanical identification is tricky. On the other hand, it is interesting to note that genetically-based variations were detectable on extracts from leaves from trees after planting seeds of various geographical origins. Effectively, seeds were from different genetic and geographical origins but all were cultivated in a common garden experiment (Figure 1). A maternal effect, i.e., the fact that individuals could be influenced by their mother's local environment, cannot account for the grouping of geographical origins as we used several mother plants for each geographic origin. Furthermore, we did not observe any block effect within the plantation on the metabolome (results not shown, see Table 1 for block allocation), illustrating the limited effect of the growing environment. This observation is particularly true when genetic parameters are consistent; i.e., Ouesso-Sua samples were well gathered according to their genetic filiation. In fact, the genetic microsatellite markers allowed us to identify the species (always) and often to confirm or to identify the family of a specimen or population of origin, especially 
in E. suaveolens where our markers are more polymorphic. As a consequence, heatmap (Figure 3) and PCA (Figure 2B) confirm it from a metabolomics point of view.

In Erythrophleum, reproduction occurs mainly by cross-fertilization so that genetic differentiation is not very strong between families and each family may contain a good genetic diversity. In the case of E. ivorense, collecting areas were geographically closed (Libreville area) and the non-specific gene breeding is more possible. As a consequence, neutral genetic markers are enabled to discriminate families. Heatmap (Figure 3 ) and PCA (Figure 2B) clearly separated two sub-clusters ivo-Libr 1 et ivo-Libr 2 in E. ivorense, meaning that the metabolome is influenced by either genetic considerations not measured by genetic markers or by environmental factors. However, although the leaflets of all the studied trees were sampled the same day, seeking only mature leaflets, we cannot exclude that part of their metabolomic variation was influenced by differences in leaf maturity or by uncontrolled stress factors.

Within E. suaveolens, the two metabolomic clusters identified separated samples from the easternmost population from the other ones. This correlation cannot result from direct environmental growth effects on the metabolome because trees were grown in a common garden experiment, demonstrating a genetic determinism. Interestingly, the expression of this genetic variation through metabolites did not coincide with the main genetic macrogeographic variation detected using neutral microsatellite markers which highlights a north-south differentiation [16]). If metabolomic variation is non-neutral, which is likely for molecules that are costly to produce, it is possible that natural selection contributed to generate a geographic pattern in response to local adaptation pressures, not visible using neutral markers. Within E. ivorense, the two metabolomic clusters are not associated with different geographic origins. Here, we cannot assess whether this metabolomic variation results from a genetic determinism showing local polymorphism or from uncontrolled environmental factors. We would have needed several samples per tree, possibly taken at different periods, to be able to tease apart environmental and genetic determinism.

As matter of fact, metabolomics allowed us to classify the samples according to their species and, to some extent, according to geographical origin. In this context, it was interesting to identify the discriminant metabolites.

Heatmap feature clustering is convenient for the first step of annotation as it allows identifying the features-metabolites-of interest. For example, in subcluster ivo-Libr 1 , features cluster 4 (Figure 3) is over-expressed. Then molecular network construction is of high interest to identify and to annotate those metabolites as this method allows linking MS features and molecular chemistry (Figures 5 and 6). Cassane-type diterpenes, which are original chemical signatures of Erythrophleum genus [24] are well adapted to annotation by molecular networks. Indeed, with their diterpenoids tri-cyclic ring $(\mathrm{m} / \mathrm{z}$ 255) substituted by ester, amide, acetoxy or hydroxyl, they have common fragments and neutral losses that allowed in the present study to MetGem to create a well-defined cluster (Figure 5). Moreover, and as several cassane-type diterpenes are described in literature, attempts of molecular assignments are possible based on the well-known structures. First, all the cassane-type diterpenes found were derived from cassamine and as a consequence, carried an amine esterified arm with an ester linkage. No amide derivatives with an alcohol have been identified and various substitutions have been observed on the diterpene cycle. Moreover, and thanks to the molecular network, we found 19 new cassane diterpenes (Table 2). Second, we noticed that E. ivorense was characterized by complex $3 \beta$-alkyl compound with tigloyl, methylcrotonyl or o-glucosyl derivatives. They are also abundant in the extract when comparing the signal abundance by mass spectrometry (Figure 6, bottom). This statement was also confirmed by Biosigner analysis comparing E. ivorense and $E$. suaveolens populations that showed those compounds were significantly higher in $E$. ivorense and consequently are a chemical signature of this species.

Regarding compounds that discriminate ivo-Libr 1 from ivo-Libr 2, only one compound [B11] in the cassane-type diterpene cluster can be emphasized. However, in cluster 
4, quercetin analogs seemed present in higher amount in ivo-Libr 1. The direct consequence, is the fact that $E$. suaveolens is characterized by cassane-type diterpene with lower masses. For instance, $3 \beta$-acetate-4-acetoxy derivatives are well represented in Sua * subgroup while Ouesso-Sua is characterized by $3 \beta$-hydroxy-4-acetoxy derivatives. Moreover, the other clusters in the molecular network showed that Sua * can be differentiated by the presence of catechin derivatives (cluster 2), mono- or di-O-glycoside-flavonoids (cluster 4) and a trihydroxyflavanone derivative (cluster 8) (Figure 6, top).

To sum up, this study has been carried out on wild plants where the seeds are collected in a wide area and grew in a homogenous environment. Metabolomics has demonstrated its strength to properly discriminate the species and some sub-groups. It is complementary to genetic analysis using microsatellite markers to discriminate groups. Moreover, metabolomics conserves the markers related to genetics and the geographical origins despite the fact that the growing was a new controlled environment (Pallisco) on wild plants.

We were unable to conclude whether the genetic is solely the determinant or if the geographical origin could also have an impact-by epigenetic perhaps. It is also difficult to link the different metabolites with the genetic diversity as the chemical pathways are not totally elucidated for cassane-type diterpenes. Nevertheless, this study demonstrates that metabolomics could properly separate genetic variants (species, populations) of plant seeds even if they grew in the same environment which could help biologists to properly characterize plants from unknown origin. It remains to be demonstrated that these data are stable in different environments and over time. This study offers a better comprehension of the chemical diversity and content in key secondary metabolites with pharmaceutical interest. This study could be useful to help in the seed origin selection for reasonable culture of this threatened species.

\section{Materials and Methods}

\subsection{Field Sampling}

In 2007, seeds of E. suaveolens and E. ivorense were collected under 30 trees ('families') in five sites of Cameroon, Gabon and the Republic of Congo, and were conserved dried. In March 2008, the seeds were soaked 10-15 min in a 90\% sulfuric acid solution to break their dormancy. They were then planted separately in two liters polyethylene bags filled with potting soil in the nursery of the logging company Pallisco, in southeastern Cameroon $\left(3^{\circ} 28^{\prime} \mathrm{N}, 13^{\circ} 34^{\prime} \mathrm{E}\right)$. In March 2009, most seedlings were 30-70 cm high and 20 seedlings from each of 20 families were transplanted with a spacing of $3 \mathrm{~m}$ on a cleared horizontal parcel of c. 0.4 ha near the Pallisco headquarter to monitor their growth in identical environmental conditions (http:/ / www.dynaffor.org/ (accessed on January 2021)). This common garden experiment was made of 20 rectangular blocks $(12 \times 15 \mathrm{~m})$ and each family was represented once per block (random block design). The site is located on Ferralsols at $650 \mathrm{~m}$ asl and the climate is Guinean equatorial (pluviosity: 1550-1750 mm/yr; mean monthly temperature: $22-2{ }^{\circ} \mathrm{C}$ ). The two first years, when a seedling died it was replaced by another seedling from the nursery. In January 2015, trees had reached a mean height of c. $11 \mathrm{~m}$ and c. $10 \%$ had died since the transplantation. Ten mature leaflets (leaves) were then sampled in four blocks named A to D on 23 trees belonging to E. ivorense and 21 trees belonging to E. suaveolens (Table 1). Leaflets of each individual were air-dried after harvest for at least $72 \mathrm{~h}$ and were not exposed to sun. Trees belonging to E. suaveolens came from three geographical origins (populations) and two genetic groups-called Sua(S) and Sua(N) (as determined by neutral microsatellite markers) [16] (Table 1). The purpose of growing all plants together in the same plot (common garden experiment) was to assure that all will be exposed to the same environmental conditions (same soil factors, sun exposure, wind, etc.). Consequently, the metabolomic differences we might observe would mainly result from genetically-based differences and not from environmental effects.

The experimental sampling design and the metabolomics carried out in the current study are illustrated in Figure 2. Data were first preprocessed and statistically analyzed with the Workflow4Metabolomics (W4M) platform $[27,53]$. $\mathrm{MS}^{2}$ data were preprocessed 
in MZmine 2 and molecular networks were constructed in MetGem software [28]. The complete workflow allowed us to perform a holistic identification of samples.

\subsection{Controlling the Identification and Origin of Samples}

As leaves of both species are morphologically indistinguishable, samples were genotyped with nine microsatellites to check species identity following Duminil et al. [16] (data not shown). These data also allowed checking the coherence of geographical origin. It appeared that seeds sampled below a same tree (called 'family' here) are not always sibs (results not shown) because secondary seed dispersal is frequent in Erythrophleum [54]. Therefore, the smallest unit to group samples and check for potential genetic effects was the population of origin.

\subsection{Metabolomics Analyses}

LC-MS quality formic acid (FA), acetonitrile (ACN) and methanol were purchased from Sigma Aldrich (Steinheim, Germany). High purity water was prepared using a Milli-Q system from Millipore (Bedford, MA, USA).

\subsubsection{Sample Preparation}

Each dry sample (leaves) was grounded before being extracted on batches of $15 \mathrm{mg}$ of powdered leaves in $1.5 \mathrm{~mL}$ of pure methanol for $5 \mathrm{~min}$ in a $55 \mathrm{kHz}$ ultrasonic bath at room temperature. Three extraction replicates per sample were performed. Samples were filtered on $0.22 \mu \mathrm{m}$ membrane and stored in $-20{ }^{\circ} \mathrm{C}$ before analysis.

\subsubsection{LC-HRMS(/MS) Analysis}

Analyses were performed using a 1200 series rapid resolution liquid chromatograph (RRLC) coupled to a 6520 series electrospray ionization (ESI)-quadrupole time-of-flight (QTOF) high-resolution mass spectrometer (HRMS) from Agilent Technologies (Waldbronn, Germany). Compound separation was performed using a Poroshell 120 EC-C18 column $(2.1 \times 100 \mathrm{~mm}, 2.7 \mu \mathrm{m}$ particle size, Agilent Technologies, Palo Alto, CA, USA). The column temperature was set at $40{ }^{\circ} \mathrm{C}$. The mobile phases used in all experiments were composed of water acidified with $0.1 \%$ formic acid (FA) (solvent $\mathrm{A}$ ) and acidified acetonitrile $(0.1 \% \mathrm{FA})$ (solvent B). The applied gradient was as follows: $0 \mathrm{~min}, 5 \% \mathrm{~B} ; 0-20 \mathrm{~min}, 75 \% \mathrm{~B} ; 20-25 \mathrm{~min}$, $75 \% \mathrm{~B}$; in $1 \mathrm{~min}$ back to $5 \% \mathrm{~B}$; and $26-30 \mathrm{~min}, 5 \% \mathrm{~B}$; post-run $5 \mathrm{~min}$ at $0.2 \mathrm{~mL} / \mathrm{min}$. ESIQTOF parameters were as follows for simple MS analysis: positive mode, $2 \mathrm{GHz}$ resolution, MS scan range $100-1600 \mathrm{~m} / z$ at 2 spectra/s, drying gas temperature $350{ }^{\circ} \mathrm{C}$, drying gas flow $9 \mathrm{~L} / \mathrm{min}$, nebulizer pressure 50 psi, capillary voltage $4000 \mathrm{~V}$, Fragmentor $175 \mathrm{~V}$. Nitrogen was used as nebulizer gas. Continuous infusion of two reference ions, respectively $m / z 121.050873$ and 922.009798, was performed for QTOF continuous calibration. Data acquisition and analysis were carried out by MassHunter Acquisition ${ }^{\circledR}$ software for QTOF (Version B.04 SP3) and MassHunter Qualitative Analysis ${ }^{\circledR}$ (Version B.07) software (both from Agilent Technologies). Samples were randomly analyzed in one batch. The same quality control (QC) sample (=mix of all samples) was injected throughout the run after every ten samples approximately for control and blanks (water with $0.1 \%$ FA) were also injected throughout the run.

For molecular network and standard analysis, a LC-autoMS/MS analysis was performed with the following conditions for the ESI-QTOF: MS scan range 100-1600 m/z at 4 spectra/s; MS inclusion list: $250-900 \mathrm{~m} / z$; MS/MS scan range 100-1600 at 3 spectra/s; isolation width: medium mode $(\approx 4 \mathrm{~m} / z)$; fixed collision energy was $25 \mathrm{eV}$ for the molecular network and 5, 25, $50 \mathrm{eV}$ for the standard analysis; max precursors at $3 / \mathrm{cy}-$ cle; threshold 2000 absolute intensities.; Precursor abundance based scan speed at 25,000 counts/spectrum with MS/MS accumulation time limit; active exclusion after 3 spectra released after $0.5 \mathrm{~min}$; precursor sort by abundance for charges of 1 or 2 . 


\subsubsection{Metabolomics Data}

Agilent format ".d" data were converted to ".mzXML" format using the ProteoWizard MSConvert tools (Version 3.03.9393, 64-bit) with following parameters: binary encoding precision $=32$ bit, write index: yes, use zlib compression: yes, TPP compatibility: yes, with the Peak Picking filter option with only MS level 1.

\subsubsection{Data Processing and Chemometrics on W4M}

Preprocessing (filtration, peak identification, peak grouping and smoothing, retention time correction, integration, annotation), normalization, quality control (metabolites correlation analysis and determination of batch correction), statistical analysis (univariate testing and multivariate modeling) were conducted using the Galaxy workflow4metabolomics W4M (http:/ / workflow4metabolomics.org) [27]. The entire analysis has been processed on 170 samples (samples including extraction replicates + blank + Quality Control samples).

\subsubsection{Statistical Analyses}

Heatmaps, principal component analysis (PCA) and partial least squares-discriminant analysis (PLS-DA) were performed to visualize the distribution of metabolite variability using W4M platform. The Biosigner tool was used to select the variables which are significant and best distinguish two groups of samples [51] on the W4M platform. Three binary classifiers have been run in parallel, namely partial least squares-discriminant analysis (PLS-DA), random forest and support vector machines (SVM).

\subsubsection{Data Preprocessing with MZmine 2 and Molecular Network Analysis with MetGem}

mzXML files of autoMSMS analyses were further processed using MZmine 2.53 software [29]. Range time was filtered on 5-24 $\mathrm{min}$ as it is the part of interest in the chromatograms. Mass detection was performed by fixing the noise level at 2000 for MS1 and 50 for MS2. ADAP Chromatogram Builder was used to build chromatograms with a minimum group size of three scans, a group intensity at 50 and a minimum intensity at 50. The $m / z$ tolerance was fixed at 0.008 or $24 \mathrm{ppm}$. Wavelet (ADAP) method was used for deconvolution with a $\mathrm{S} / \mathrm{N}$ at 8 , a minimum feature height at 500, a coefficient/area threshold at 10, a peak duration range of $0.01-0.50$ and a retention time (RT) wavelet range of 0.01-0.09 min. This deconvolution was performed with a $m / z$ range for MS2 scan pairing of $0.02 \mathrm{Da}$ and a RT range for MS2 scan pairing of $0.25 \mathrm{~min}$. Isotopic peak grouper was then performed using the following parameters: $\mathrm{m} / z$ tolerance $=0.008 \mathrm{amu}$ or $24.0 \mathrm{ppm}$, RT tolerance $=0.25 \mathrm{~min}$, maximum charge $=1$. Peak list was then generated using join aligner for data alignment with the following parameters: $\mathrm{m} / \mathrm{z}$ tolerance $=0.08 \mathrm{amu}$ or $24 \mathrm{ppm}$, weight for $m / z=75$, RT tolerance $=0.5 \mathrm{~min}$, weight for RT $=25$. Gal filler option was performed using the same RT and $\mathrm{m} / \mathrm{z}$ range method with a $\mathrm{m} / \mathrm{z}$ tolerance at 0.008 amu or $24.0 \mathrm{ppm}$. A filter to keep only peaks with MS2 scan (GNPS), minimum peaks in a row of 1 and minimum peaks in an isotope pattern of 1 . Data were then exported as .mgf files for spectra and .csv files for metadata information (intensities, RT ... ). We used .csv file to calculate means of areas of MS1 for each feature of each sample in the same group observed in heatmap (Figure 4). MetGem 1.3.4 software was used for building the molecular networks (https:/ / metgem.github.io/, [28]). Data ".mgf" and ".csv" files were imported using standard parameters $(m / z$ tolerance $=0.02$; minimum matched peaks $=4$. Networks were then created where edges were filtered to have a cosine score (CS) above 0.55 , maximum neighbor number (top K) of 10 and a max. connected component size of 1000 .

Supplementary Materials: Figure S1: Fragmentation pattern characteristics of amide compounds (A) or ester compound (B). The amide compound is characterized by a neutral loss of $\mathrm{H}_{2} \mathrm{O}$ and $\mathrm{MeOH}$, while the ester compound is characterized by a neutral loss of solely $\mathrm{NH}(\mathrm{Me})_{2}$.

Author Contributions: Conceptualization, N.N., F.S., C.S. and O.J.H.; formal analysis, C.D., O.J.H., M.T.-F., A.G., M.F., P.V.A. and F.S.; funding acquisition, C.S. and P.V.A.; methodology, C.D., N.N., 
P.V.A., F.S.; software, C.D., F.S., D.T., M.T.-F., and C.V.; validation, C.D., F.S. and C.V.; investigation, C.D., F.S., D.T., A.G., M.F., M.T.-F., J.-F.M., C.V. and P.V.A.; project administration, M.F., C.S., and F.S.; resources, A.G., O.J.H.; data curation, C.D.,N.N., F.S., D.T., J.-F.M., C.V. and P.V.A.; Supervision, F.S.; writing-original draft preparation, C.D., F.S., C.V. and P.V.A.; writing-review and editing, C.D., N.N., O.J.H., D.T., M.T.-F., J.-F.M., C.S., P.V.A., F.S. and C.V. All authors have read and agreed to the published version of the manuscript.

Funding: LC-MS platform was supported by the Belgian National Fund for Scientific Research (FRS, $\mathrm{N}^{\circ}$ 3.4553.08 and T.0136.13 PDR) and the Université libre de Bruxelles (FER-2007).

Institutional Review Board Statement: Not applicable.

Informed Consent Statement: Not applicable.

Data Availability Statement: Data are available at this link when you are logged on W4M platform: https:/ / workflow4metabolomics.usegalaxy.fr/histories/list_published under name “Erythro Clean 01 " by author F. Souard.

Acknowledgments: C.D. thanks Margot, F.S. thanks Léonie. The authors warmly thank P. Champy and colleagues and in particular L. Kablan for their help, providing samples useful for the identification of cassaine-type diterpenoids.

Conflicts of Interest: The authors declare no conflict of interest.

Sample Availability: Samples of the compounds are not available from the authors.

\section{References}

1. Kami, C.; Lorrain, S.; Hornitschek, P.; Fankhauser, C. Light-Regulated Plant Growth and Development. Curr. Top. Dev. Biol. 2010, 91, 29-66. [CrossRef]

2. Quint, M.; Delker, C.; Franklin, K.A.; Wigge, P.A.; Halliday, K.J.; van Zanten, M. Molecular and Genetic Control of Plant Thermomorphogenesis. Nat. Plants 2016, 2, 15190. [CrossRef]

3. Verma, V.; Ravindran, P.; Kumar, P.P. Plant Hormone-Mediated Regulation of Stress Responses. BMC Plant Biol. 2016, 16, 86. [CrossRef]

4. Zhu, J.-K. Abiotic Stress Signaling and Responses in Plants. Cell 2016, 167, 313-324. [CrossRef] [PubMed]

5. Saito, K. Editorial: The Origin of Plant Chemodiversity - Conceptual and Empirical Insights. Front. Plant Sci. 2020, 11, 890. [CrossRef]

6. Fang, C.; Fernie, A.R.; Luo, J. Exploring the Diversity of Plant Metabolism. Trends Plant Sci. 2019, 24, 83-98. [CrossRef]

7. Jamil, I.N.; Remali, J.; Azizan, K.A.; Nor Muhammad, N.A.; Arita, M.; Goh, H.-H.; Aizat, W.M. Systematic Multi-Omics Integration (MOI) Approach in Plant Systems Biology. Front. Plant Sci. 2020, 11, 944. [CrossRef]

8. Dixon, R.A.; Strack, D. Phytochemistry Meets Genome Analysis, and Beyond. Phytochemistry 2003, 62, 815-816. [CrossRef]

9. Rai, A.; Saito, K.; Yamazaki, M. Integrated Omics Analysis of Specialized Metabolism in Medicinal Plants. Plant J. Cell Mol. Biol. 2017, 90, 764-787. [CrossRef] [PubMed]

10. Arbona, V.; Manzi, M.; de Ollas, C.; Gómez-Cadenas, A. Metabolomics as a Tool to Investigate Abiotic Stress Tolerance in Plants. Int. J. Mol. Sci. 2013, 14, 4885-4911. [CrossRef] [PubMed]

11. Kooke, R.; Keurentjes, J.J.B. Multi-Dimensional Regulation of Metabolic Networks Shaping Plant Development and Performance. J. Exp. Bot. 2012, 63, 3353-3365. [CrossRef]

12. Macel, M.; Van Dam, N.M.; Keurentjes, J.J.B. Metabolomics: The Chemistry between Ecology and Genetics. Mol. Ecol. Resour. 2010, 10, 583-593. [CrossRef] [PubMed]

13. Marchev, A.S.; Koycheva, I.K.; Aneva, I.Y.; Georgiev, M.I. Authenticity and Quality Evaluation of Different Rhodiola Species and Commercial Products Based on NMR-Spectroscopy and HPLC. Phytochem. Anal. PCA 2020, 31, 756-769. [CrossRef]

14. Liu, F.; Meng, Y.; He, K.; Song, F.; Cheng, J.; Wang, H.; Huang, Z.; Luo, Z.; Yan, X. Comparative Analysis of Proteomic and Metabolomic Profiles of Different Species of Paris. J. Proteomics 2019, 200, 11-27. [CrossRef] [PubMed]

15. Gang, F.; Qi, L.I.; Xin-Mei, X.U.; Huan, D.U.; Tong, X.U.; Xian-Rong, L.; Lei-Lei, D.U. [Quality evaluation of different Berberidis Cortex species based on $1 \mathrm{H}-\mathrm{NMR}$ metabolomics and anti-diabetic activity]. Zhongguo Zhong Yao Za Zhi Zhongguo Zhongyao Zazhi China J. Chin. Mater. Medica 2020, 45, 4677-4685. [CrossRef]

16. Duminil, J.; Brown, R.P.; Ewédjè, E.-E.B.; Mardulyn, P.; Doucet, J.-L.; Hardy, O.J. Large-Scale Pattern of Genetic Differentiation within African Rainforest Trees: Insights on the Roles of Ecological Gradients and Past Climate Changes on the Evolution of Erythrophleum Spp (Fabaceae). BMC Evol. Biol. 2013, 13, 195. [CrossRef]

17. Dade, J.M.E.; Kablan, L.A.; Okpekon, T.A.; Say, M.; Yapo, K.D.; Komlaga, G.; Boti, J.B.; Koffi, A.P.; Guei, L.E.; Djakoure, L.A.; et al. Cassane Diterpenoids from Stem Bark of Erythrophleum Suaveolens [(Guill. et Perr.), Brenan]. Phytochem. Lett. 2015, 12, $224-231$. [CrossRef] 
18. Kablan, A.C.L.; Konan, J.D.; Komlaga, G.; Kabran, F.A.; Daouda, B.; N’Tamon, A.D.; Kouamé, T.; Jagora, A.; Leblanc, K.; Seon-Méniel, B.; et al. Five New Cassane Diterpenes from the Seeds and Bark of Erythrophleum Suaveolens. Fitoterapia 2020, 146, 104700. [CrossRef]

19. Kablan, L.A.; Dade, J.M.E.; Say, M.; Okpekon, T.A.; Yapo, K.D.; Ouffoue, S.K.; Koffi, A.P.; Retailleau, P.; Champy, P. Four New Cassane Diterpenoid Amides from Erythrophleum Suaveolens [(Guill. et Perr.), Brenan]. Phytochem. Lett. 2014, 10, 60-64. [CrossRef]

20. Son, N.T. Genus Erythrophleum: Botanical Description, Traditional Use, Phytochemistry and Pharmacology. Phytochem. Rev. 2019, 18, 571-599. [CrossRef]

21. Dalma, G. Chapter 36 The Erythrophleum Alkaloids. In The Alkaloids: Chemistry and Physiology; Manske, R.H.F., Holmes, H.L., Eds.; Academic Press: Cambridge, MA, USA, 1954; Volume 4, pp. 265-273.

22. Jing, W.; Zhang, X.; Zhou, H.; Wang, Y.; Yang, M.; Long, L.; Gao, H. Naturally Occurring Cassane Diterpenoids (CAs) of Caesalpinia: A Systematic Review of Its Biosynthesis, Chemistry and Pharmacology. Fitoterapia 2019, 134, 226-249. [CrossRef]

23. Coates, R.M. Biogenetic-Type Rearrangements of Terpenes. In Fortschritte der Chemie Organischer Naturstoffe/Progress in the Chemistry of Organic Natural Products; Cimino, G., Coates, R.M., De Stefano, S., Fontana, A., Hemmerich, P., Minale, L., Rinehart, K.L., Shield, L.S., Sodano, G., Toniolo, C., et al., Eds.; Fortschritte der Chemie Organischer Naturstoffe/Progress in the Chemistry of Organic Natural Products; Springer: Vienna, Austria, 1976; pp. 73-230. ISBN 978-3-7091-3262-3.

24. Maurya, R.; Ravi, M.; Singh, S.; Yadav, P.P. A Review on Cassane and Norcassane Diterpenes and Their Pharmacological Studies. Fitoterapia 2012, 83, 272-280. [CrossRef] [PubMed]

25. Qu, J.; Yu, S.; Tang, W.; Liu, Y.; Liu, Y.; Liu, J. Progress on Cassaine-Type Diterpenoid Ester Amines and Amides ( Erythrophleum Alkaloids). Nat. Prod. Commun. 2006, 1, 1934578X0600101. [CrossRef]

26. Qu, J.; Wang, Y.-H.; Li, J.-B.; Yu, S.-S.; Li, Y.; Liu, Y.-B. Rapid Structural Determination of New Trace Cassaine-Type Diterpenoid Amides in Fractions from Erythrophleum Fordii by Liquid Chromatography-Diode-Array Detection/Electrospray Ionization Tandem Mass Spectrometry and Liquid Chromatography/Nuclear Magnetic Resonance. Rapid Commun. Mass Spectrom. 2007, 21, 2109-2119. [CrossRef] [PubMed]

27. Giacomoni, F.; Le Corguillé, G.; Monsoor, M.; Landi, M.; Pericard, P.; Pétéra, M.; Duperier, C.; Tremblay-Franco, M.; Martin, J.-F.; Jacob, D.; et al. Workflow4Metabolomics: A Collaborative Research Infrastructure for Computational Metabolomics. Bioinformatics 2015, 31, 1493-1495. [CrossRef]

28. Olivon, F.; Elie, N.; Grelier, G.; Roussi, F.; Litaudon, M.; Touboul, D. MetGem Software for the Generation of Molecular Networks Based on the T-SNE Algorithm. Anal. Chem. 2018, 90, 13900-13908. [CrossRef]

29. Pluskal, T.; Castillo, S.; Villar-Briones, A.; Oresic, M. MZmine 2: Modular Framework for Processing, Visualizing, and Analyzing Mass Spectrometry-Based Molecular Profile Data. BMC Bioinform. 2010, 11, 395. [CrossRef] [PubMed]

30. Ernst, M.; Kang, K.B.; Caraballo-Rodríguez, A.M.; Nothias, L.-F.; Wandy, J.; Chen, C.; Wang, M.; Rogers, S.; Medema, M.H.; Dorrestein, P.C.; et al. MolNetEnhancer: Enhanced Molecular Networks by Integrating Metabolome Mining and Annotation Tools. Metabolites 2019, 9, 144. [CrossRef]

31. Armah, F.A.; Amponsah, I.K.; Mensah, A.Y.; Dickson, R.A.; Steenkamp, P.A.; Madala, N.E.; Adokoh, C.K. Leishmanicidal Activity of the Root Bark of Erythrophleum Ivorense (Fabaceae) and Identification of Some of Its Compounds by Ultra-Performance Liquid Chromatography Quadrupole Time of Flight Mass Spectrometry (UPLC-QTOF-MS/MS). J. Ethnopharmacol. 2018, 211, 207-216. [CrossRef]

32. Friedrich-Fiechtl, J.; Spiteller, G. [Use of Mass Spectrum Analysis for Structure Elucidation of Alkaloids. X. New Alkaloids from Erythrophleum Guineense and about Muawin]. Chem. Ber. 1971, 104, 3335-3348. [CrossRef] [PubMed]

33. Konan, J.D.; Attioua, B.K.; Kablan, C.L.A.; Kabran, F.A.; Koffi, P.A.; Any-Grah, S.A.; Drissa, S.; Seon-Meniel, B.; LeBlanc, K.; Jullian, J.-C.; et al. New Cassane Diterpenoids from the Root Bark of Erythrophleum Suaveolens. Phytochem. Lett. 2019, 31, 166-169. [CrossRef]

34. Loder, J.W.; Culvenor, C.C.J.; Nearn, R.H.; Russel, G.B.; Stanton, D.W. Isolation of Norcassamidide and Authentic Norcassamidine from Erythrophleum Chlorostachys. Structural Revision of the Alkaloids Previously Known as Norcassamidine, Norcassamine, Norethythrosuamine and Dehydro-Norerythrosuamine. Tetrahedron Lett. 1972, 13, 5069-5072. [CrossRef]

35. Arya, V.P.; Engel, B.G.; Ronco, A. Zur Kenntnis Der Erythrophleum-Alkaloide. 17. Mitteilung. Über Einige Für Die Konstitutionsbestimmung von Cassamin Wichtige Derivate Der Cassan-19-Säure. Helv. Chim. Acta 1961, 44, 1645-1650. [CrossRef]

36. Arya, V.P.; Engel, B.G. Zur Kenntnis der Erythrophleum-Alkaloide. 18. Mitteilung. Die Struktur des Cassamins und des Erythrophlamins. Helv. Chim. Acta 1961, 44, 1650-1673. [CrossRef]

37. Cronlund, A. Two New Alkaloids from Bark of Erythrophleum Ivorense. Acta Pharm. Suec. 1973, 10, 507-514.

38. Cronlund, A. The Botanical and Phytochemical Differentiation between Erythrophleum Suaveolens and E. Ivorense. Planta Med. 1976, 29, 123-128. [CrossRef] [PubMed]

39. Cronlund, A.; Oguakwa, J.U. Alkaloids from the Bark of Erythrophleum Couminga. Acta Pharm. Suec. 1975, 12, 467-478. [PubMed]

40. Hung, T.M.; Cuong, T.D.; Kim, J.A.; Tae, N.; Lee, J.H.; Min, B.S. Cassaine Diterpene Alkaloids from Erythrophleum Fordii and Their Anti-Angiogenic Effect. Bioorg. Med. Chem. Lett. 2014, 24, 168-172. [CrossRef]

41. Sandberg, F. Medicinal and Toxic Plants from Equatorial Africa: A Pharmacologic Approach. J. Ethnopharmacol. 1980, 2, 105-108. [CrossRef] 
42. Albuquerque, U.P.; do Nascimento, A.L.B.; Silva Chaves, L.; Feitosa, I.S.; de Moura, J.M.B.; Gonçalves, P.H.S.; da Silva, R.H.; da Silva, T.C.; Ferreira Júnior, W.S. The Chemical Ecology Approach to Modern and Early Human Use of Medicinal Plants. Chemoecology 2020, 30, 89-102. [CrossRef]

43. Loder, J.W.; Nearn, R.H. 3ß-Acetoxynorerythrosuamine, a Highly Cytotoxic Alkaloid from Erythrophleum Chlorostachys. Chemistry 1975. [CrossRef]

44. Du, D.; Qu, J.; Wang, J.-M.; Yu, S.-S.; Chen, X.-G.; Xu, S.; Ma, S.-G.; Li, Y.; Ding, G.-Z.; Fang, L. Cytotoxic Cassaine DiterpenoidDiterpenoid Amide Dimers and Diterpenoid Amides from the Leaves of Erythrophleum Fordii. Phytochemistry 2010, 71, 1749-1755. [CrossRef] [PubMed]

45. Huang, X.; Chen, Z.; Zhou, S.; Huang, P.; Zhuo, Z.; Zeng, S.; Wang, L.; Wang, Y.; Xu, C.; Tian, H. Cassaine Diterpenoids from the Seeds of Erythrophleum Fordii and Their Cytotoxic Activities. Fitoterapia 2018, 127, 245-251. [CrossRef]

46. Verotta, L.; Aburjai, T.; Rogers, C.B.; Dorigo, P.; Maragno, I.; Fraccarollo, D.; Santostasi, G.; Gaion, R.M.; Floreani, M.; Carpenedo, F. Chemical and Pharmacological Characterization of Erythrophleum Lasianthum Alkaloids. Planta Med. 1995, 61, 271-274. [CrossRef]

47. Aron, A.T.; Gentry, E.C.; McPhail, K.L.; Nothias, L.-F.; Nothias-Esposito, M.; Bouslimani, A.; Petras, D.; Gauglitz, J.M.; Sikora, N.; Vargas, F.; et al. Reproducible Molecular Networking of Untargeted Mass Spectrometry Data Using GNPS. Nat. Protoc. 2020, 15, 1954-1991. [CrossRef] [PubMed]

48. Nothias, L.-F.; Petras, D.; Schmid, R.; Dührkop, K.; Rainer, J.; Sarvepalli, A.; Protsyuk, I.; Ernst, M.; Tsugawa, H.; Fleischauer, M.; et al. Feature-Based Molecular Networking in the GNPS Analysis Environment. Nat. Methods 2020, 17, 905-908. [CrossRef] [PubMed]

49. Phelan, V.V. Feature-Based Molecular Networking for Metabolite Annotation. Methods Mol. Biol. Clifton NJ 2020, $2104,227-243$. [CrossRef]

50. Wang, M.; Carver, J.J.; Phelan, V.V.; Sanchez, L.M.; Garg, N.; Peng, Y.; Nguyen, D.D.; Watrous, J.; Kapono, C.A.; Luzzatto-Knaan, T.; et al. Sharing and Community Curation of Mass Spectrometry Data with Global Natural Products Social Molecular Networking. Nat. Biotechnol. 2016, 34, 828-837. [CrossRef] [PubMed]

51. Rinaudo, P.; Boudah, S.; Junot, C.; Thévenot, E.A. Biosigner: A New Method for the Discovery of Significant Molecular Signatures from Omics Data. Front. Mol. Biosci. 2016, 3, 26. [CrossRef]

52. Ha, M.T.; Tran, M.H.; Phuong, T.T.; Kim, J.A.; Woo, M.H.; Choi, J.S.; Lee, S.; Lee, J.H.; Lee, H.K.; Min, B.S. Cytotoxic and Apoptosis-Inducing Activities against Human Lung Cancer Cell Lines of Cassaine Diterpenoids from the Bark of Erythrophleum Fordii. Bioorg. Med. Chem. Lett. 2017, 27, 2946-2952. [CrossRef]

53. Guitton, Y.; Tremblay-Franco, M.; Le Corguillé, G.; Martin, J.-F.; Pétéra, M.; Roger-Mele, P.; Delabrière, A.; Goulitquer, S.; Monsoor, M.; Duperier, C.; et al. Create, Run, Share, Publish, and Reference Your LC-MS, FIA-MS, GC-MS, and NMR Data Analysis Workflows with the Workflow4Metabolomics 3.0 Galaxy Online Infrastructure for Metabolomics. Int. J. Biochem. Cell Biol. 2017, 93, 89-101. [CrossRef] [PubMed]

54. Hardy, O.J.; Delaide, B.; Hainaut, H.; Gillet, J.-F.; Gillet, P.; Kaymak, E.; Vankerckhove, N.; Duminil, J.; Doucet, J.-L. Seed and Pollen Dispersal Distances in Two African Legume Timber Trees and Their Reproductive Potential under Selective Logging. Mol. Ecol. 2019, 28, 3119-3134. [CrossRef] [PubMed] 